Prepared in cooperation with the

Florida Department of Environmental Protection

\title{
Water Withdrawals, Wastewater Discharge, and Water Consumption in the Apalachicola- Chattahoochee-Flint River Basin, 2005, and Water-Use Trends, 1970-2005
}

Scientific Investigations Report 2011-5130 
Cover: Photographs of the Apalachicola-Chattahoochee-Flint River Basin By Alan Cressler, U.S. Geological Survey, Georgia Water Science Center 


\section{Water Withdrawals, Wastewater Discharge, and Water Consumption in the Apalachicola- Chattahoochee-Flint River Basins, 2005, and Water-Use Trends, 1970-2005}

By Richard L. Marella and Julia L. Fanning

Prepared in cooperation with the

Florida Department of Environmental Protection

Scientific Investigations Report 2011-5130 


\title{
U.S. Department of the Interior \\ KEN SALAZAR, Secretary
}

\section{U.S. Geological Survey \\ Marcia K. McNutt, Director}

\author{
U.S. Geological Survey, Reston, Virginia: 2011
}

For more information on the USGS - the Federal source for science about the Earth, its natural and living resources, natural hazards, and the environment, visit http://www.usgs.gov or call 1-888-ASK-USGS

For an overview of USGS information products, including maps, imagery, and publications, visit http://www.usgs.gov/pubprod

To order this and other USGS information products, visit http://store.usgs.gov

Any use of trade, product, or firm names is for descriptive purposes only and does not imply endorsement by the U.S. Government.

Although this report is in the public domain, permission must be secured from the individual copyright owners to reproduce any copyrighted materials contained within this report.

Suggested citation:

Marella, R.L., and Fanning, J.L., 2011, Water withdrawals, wastewater discharge, and water consumption in the Apalachicola-Chattahoochee-Flint River Basin, 2005, and water-use trends, 1970-2005: U.S. Geological Survey Scientific Investigations Report 2011-5130, 34 p. 


\section{Acknowledgments}

The authors gratefully acknowledge the Florida Department of Environmental Protection (FDEP), Office of Water Policy, for its cooperation in the State Water-Use Program, and extend a special thanks to the following individuals who provided support or technical assistance: Janet Llewellyn, Tom Swihart, Carolyn Voyles, and Helen Light.

The authors also would like to thank U.S. Geological Survey employees Michael Deacon, Ronald S. Spencer, and Twila Darden Wilson of the Science Publishing Network for their editorial, illustration, and layout work, and Leel Knowles of the Florida Water Science Center and Steve Lawrence of the Georgia Water Science Center for their technical assistance. 


\section{Contents}

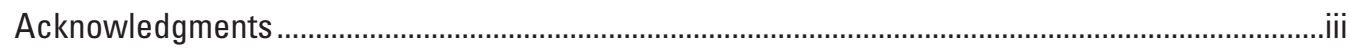

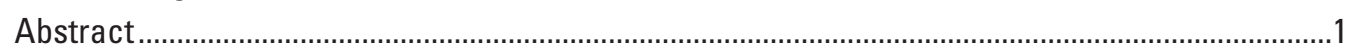

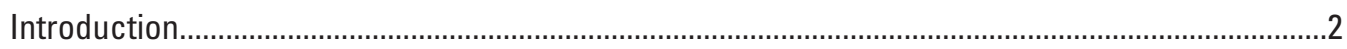

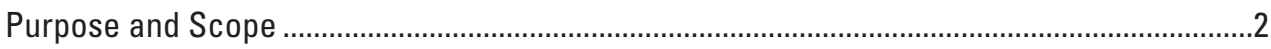

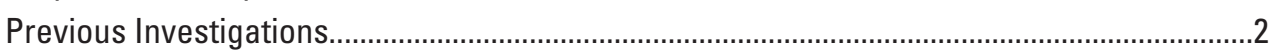

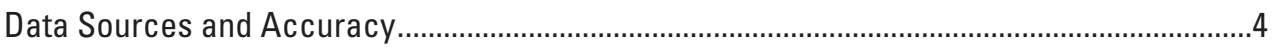

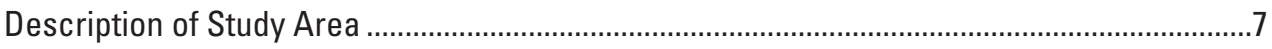

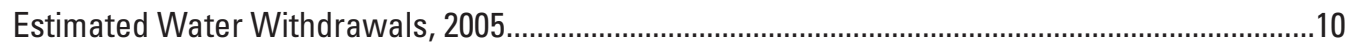

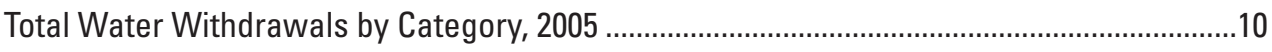

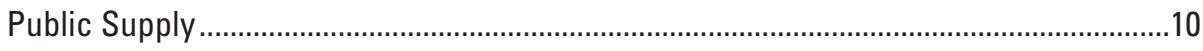

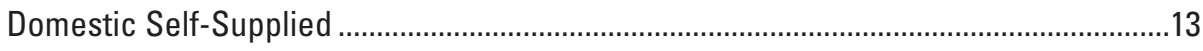

Commercial-Industrial Self-Supplied ........................................................................

Agricultural Self-Supplied (Irrigation and Nonirrigation) .................................................15

Thermoelectric Power Generation ........................................................................

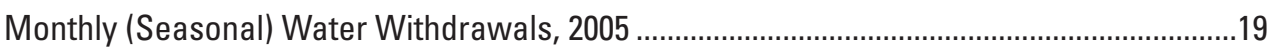

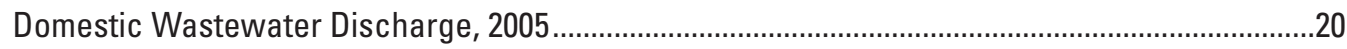

Estimated Public Supply Water Consumption, 2000 and 2005 .....................................................2

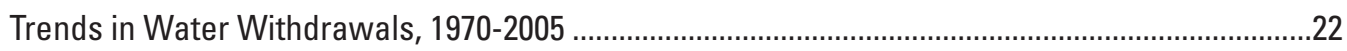

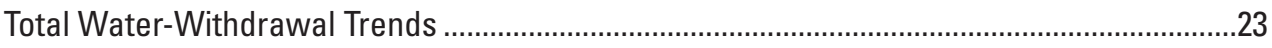

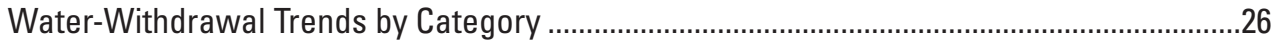

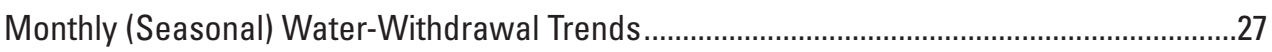

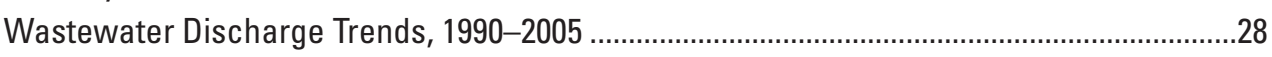

Summary

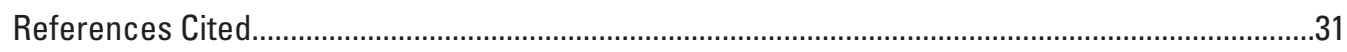

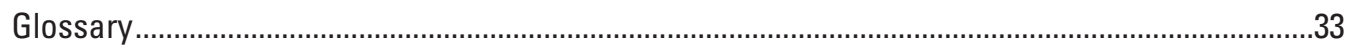

\section{Figures}

1. Map showing location of the Apalachicola-Chattahoochee-Flint River Basin and

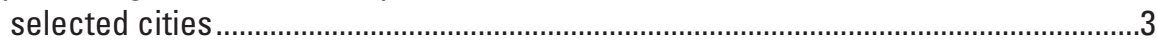

2. Graph showing total population and population served by public supply in the Apalachicola-Chattahoochee-Flint River Basin, 1970-2005.......................................

3. Graph showing annual and average rainfall in the Apalachicola-Chattahoochee-

Flint River Basin, 1970-2005 ..............................................................................................

4-6. Maps showing location of:

4. Major river basins within the Apalachicola-Chattahoochee-Flint

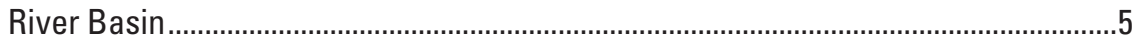

5. Counties within the Apalachicola-Chattahoochee-Flint River Basin .......................8

6. Physiographic provinces within the Apalachicola-Chattahoochee-Flint

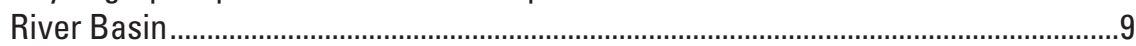

7. Map showing general location of principal aquifers used within the Apalachicola-Chattahoochee-Flint River Basin. 
8-21. Graphs showing:

8. Water withdrawals in the Apalachicola-Chattahoochee-Flint River subbasin, 2005

9. Water withdrawals by category in the Apalachicola-Chattahoochee-

Flint River Basin, 2005 by major river basin and by State

10. Public-supply average and monthly water withdrawals in the Apalachicola-Chattahoochee-Flint River Basin, 2005

11. Public-supply monthly water withdrawals by region in the Apalachicola-Chattahoochee-Flint River Basin, 2005

12. Domestic wastewater average and monthly discharges in the Apalachicola-Chattahoochee-Flint River Basin, 2005

13. Domestic wastewater discharge in the Apalachicola-ChattahoocheeFlint River Basin by region, 2005.

14. Public-supply monthly water withdrawals, domestic wastewater returns, and consumption in the Apalachicola-Chattahoochee-Flint River subbasin for 2000 and 2005

15. Total water withdrawals by water source in the ApalachicolaChattahoochee-Flint River Basin, 1970-2005.

16. Percentage of total water withdrawals by category in the Apalachicola-Chattahoochee-Flint River Basin, 1970-2005.

17. Total water withdrawals by category in the ApalachicolaChattahoochee-Flint River Basin, 1970-2005.

18. Public-supply monthly water withdrawals in the ApalachicolaChattahoochee-Flint River Basin, 1995, 2000, and 2005.

19. Public-supply water withdrawals in the Atlanta, Georgia, area of the Apalachicola-Chattahoochee-Flint River Basin and monthly basinwide rainfall, January 1990 through December 2007.

20. Public-supply water withdrawals and domestic wastewater returns in the Apalachicola-Chattahoochee-Flint River Basin, 1970-2005 30

21. Monthly domestic wastewater returns in the ApalachicolaChattahoochee-Flint River Basin, 2000, and 2005

\section{Tables}

1. Water-use data sources for Alabama, Florida, and Georgia, 2005

2. Total water withdrawals by category in the Apalachicola-Chattahoochee-Flint River Basin, 2005

3. Total water withdrawals by category in the Apalachicola-Chattahoochee-Flint River Basin by major river basin, 2005

4. Total water withdrawals by category in the Apalachicola-Chattahoochee-Flint River Basin by state, 2005

5. Freshwater withdrawals by category in the Apalachicola-Chattahoochee-Flint River Basin by county, 2005. 16-18

6. Domestic wastewater discharge by source in the Apalachicola-Chattahoochee-Flint River Basin by county, 2005

7. Freshwater withdrawals by category in the Apalachicola-Chattahoochee-Flint River Basin, 1970-2005 


\section{Conversion Factors and Abbreviations}

\begin{tabular}{rcl} 
Multiply & By & To obtain \\
& Length & \\
inch (in.) & 2.54 & centimeter $(\mathrm{cm})$ \\
inch (in.) & 25.4 & millimeter $(\mathrm{mm})$ \\
mile (mi) & 1.609 & kilometer $(\mathrm{km})$ \\
& Area & \\
acre & 4,047 & square meter $\left(\mathrm{m}^{2}\right)$ \\
acre & 0.4047 & hectare $(\mathrm{ha})$ \\
square mile (mi $\left.{ }^{2}\right)$ & 259.0 & hectare $(\mathrm{ha})$ \\
square mile (mi $\left.{ }^{2}\right)$ & 2.590 & square kilometer $\left(\mathrm{km}^{2}\right)$ \\
& Flow rate & \\
gallon per day (gal/d) & 0.003785 & cubic meter per day $\left(\mathrm{m}^{3} / \mathrm{d}\right)$ \\
million gallons per day (Mgal/d) & 0.04381 & cubic meter per second $\left(\mathrm{m}^{3} / \mathrm{s}\right)$ \\
\hline
\end{tabular}

\section{Acronyms}

\begin{tabular}{r|l} 
ADECA & Alabama Department of Economic and Community Affairs \\
ACF & Apalachicola-Chattahoochee-Flint \\
GaEPD & Environmental Protection Division \\
FDEP & Florida Department of Environmental Protection \\
NWFWMD & Northwest Florida Water Management District \\
USGS & U.S. Geological Survey
\end{tabular}




\title{
Water Withdrawals, Wastewater Discharge, and Water Consumption in the Apalachicola-Chattahoochee-Flint River Basin, 2005, and Water-Use Trends, 1970-2005
}

\author{
By Richard L. Marella and Julia L. Fanning
}

\section{Abstract}

The Apalachicola-Chattahoochee-Flint (ACF) River Basin covers about 20,500 square miles that drains parts of Alabama, Florida, and Georgia. The basin extends from its headwaters northern Georgia to the Gulf of Mexico. Population in the basin was estimated to be 3.7 million in 2005, an increase of about 41 percent from the 1990 population of 2.6 million. In 2005, slightly more than 721,000 acres of crops were irrigated within the basin.

In 2005, the total amount of water withdrawn in the ACF River Basin was about 1,990 million gallons per day (Mgal/d). Of this, surface water accounted for $1,591 \mathrm{Mgal} / \mathrm{d}$ (80 percent) and groundwater accounted for $399 \mathrm{Mgal} / \mathrm{d}$ (20 percent).

Surface water was the primary water source of withdrawals in the northern and central parts of the basin, and groundwater was the primary source in the southern part. The largest surface-water withdrawals was from Cobb County, Georgia (410 Mgal/d, mostly from the Chattahoochee River and Lake Alatoona), and the largest groundwater withdrawals was from Dougherty County, Georgia (38 Mgal/d, mostly from the Upper Floridan aquifer system).

Thermoelectric power generation accounted for the largest water withdrawals in 2005 at $788 \mathrm{Mgal} / \mathrm{d}$ (40 percent). Most of these withdrawals were used for once-through cooling, and nearly all water used for this purpose was returned to its source. Public supply accounted for $609 \mathrm{Mgal} / \mathrm{d}$ (30 percent) of total withdrawals in 2005 , followed by agricultural self-supplied (including crop, golf course irrigation, and livestock) at $365 \mathrm{Mgal} / \mathrm{d}$ (18 percent), commercial-industrial self-supplied (including mining) at $191 \mathrm{Mgal} / \mathrm{d}$ (10 percent), and domestic self-supplied at $37 \mathrm{Mgal} / \mathrm{d}$ (2 percent). Publicsupply withdrawals were lowest during January, February, and March (about $500 \mathrm{Mgal} / \mathrm{d}$ ), and highest during September (about $700 \mathrm{Mgal} / \mathrm{d}$ ).

As the population of the ACF River Basin increased by 1.7 million ( 83 percent) in the 35 years between 1970 and 2005 , total withdrawals in the basin increased by more than $515 \mathrm{Mgal} / \mathrm{d}$ (35 percent). Of this increase, surface-water accounted for $206 \mathrm{Mgal} / \mathrm{d}$ (15 percent) and groundwater accounted for $309 \mathrm{Mgal} / \mathrm{d}$ (350 percent). Since 1980, total water withdrawals have generally declined, except in 2000 when they peaked because of below-average rainfall.

In 2000, an estimated 49 percent of the water withdrawn for public supply in the basin was consumed, and the remaining 51 percent was returned to the hydrologic system through wastewater treatment systems. In 2005, an estimated 38 percent was consumed and 62 percent was returned to the hydrologic system. This contrast between water withdrawals and wastewater discharges for these years was caused primarily by below-average rainfall during 2000 (a dry year) and above-average rainfall during 2005 (a wet year). 


\section{Introduction}

The Apalachicola-Chattahoochee-Flint (ACF) River Basin covers about 20,500 square miles $\left(\mathrm{mi}^{2}\right)$ (Seaber and others, 1984) and drains parts of Alabama (Ala.), Florida (Fla.), and Georgia (Ga.) (fig. 1). The basin extends from its headwaters, north of Lake Sidney Lanier in northern Georgia, to the Apalachicola Bay in Florida, where the Apalachicola River discharges into the Gulf of Mexico. Surface water in the basin is used for public (municipal) water supply by several cities and industries, irrigation and farm operations, domestic (municipal) wastewater disposal, recreational boating and fishing, fish and wildlife propagation, and power generation. Seasonal flooding of the rivers sustains the forested flood-plain ecosystem (Darst and Light, 2008) along the Apalachicola River corridor, and provides the freshwater needed to maintain a healthy seafood industry in Apalachicola Bay (Leitman and others, 1984). Economic activities in this basin include agriculture, commercial services, silviculture (forestry), industrial manufacturing, lumber and food processing, and commercial fishing (in Apalachicola Bay).

The population of the ACF River Basin was estimated to be 3.73 million in 2005 (Hutson and others, 2009 and http:// water.usgs.gov/usgs/watuse/2005compilation/hucpop/index. $\mathrm{html}$ ). This estimate represents a population increase of about 41 percent from the 1990 population of 2.64 million (Marella and others, 1993) (fig. 2). In 2005, an estimated 63 percent (2.33 million) of the population in the basin resided in eight counties within the metropolitan Atlanta, Ga., area (Clayton, Cobb, DeKalb, Douglas, Fayette, Fulton, Gwinnett, and Henry). The large agricultural sector in the Coastal Plain of the ACF River Basin depends heavily on the groundwater resources in the basin. Slightly more than 721,000 acres of field and vegetable crops were irrigated in 2005 within the basin. In 2005, 75 percent (nearly 540,000 acres) of the irrigated acreage were located within 10 counties in southwestern Georgia (Baker, Calhoun, Decatur, Dooly, Early, Lee, Miller, Mitchell, Seminole, and Sumter).

Increasing population growth and agricultural production from the 1970s to present has substantially increased the demand on the water resources of the basin. In addition to water withdrawn for human activities, water is needed for fish and wildlife and to sustain a healthy natural ecosystem. Annual and seasonal fluctuations in rainfall further compound these issues (fig. 3), and create conflicting water demands within the basin. Improved understanding of annual and seasonal trends in the amount of water used for human activities will assist with water management of this important resource. To address this need, the U.S. Geological Survey (USGS), in cooperation with the Florida Department of Environmental Protection (FDEP), estimated water withdrawals, domestic wastewater discharge, and public-supply water consumption in the ACF River Basin for 2005, and water-use trends for 1970-2005.

\section{Purpose and Scope}

The purpose of this report is to present estimated water withdrawals, domestic wastewater discharge, and publicsupply water consumption in the ACF River Basin for 2005, and water-use trends for 1970-2005. Estimates of water withdrawn in the basin are presented for each of the following categories: public supply, domestic self-supplied, commercialindustrial self-supplied (including mining uses), agricultural self-supplied (crop irrigation, golf course irrigation, and nonirrigation uses), and thermoelectric power generation. Monthly (seasonal) public-supply water withdrawals and domestic wastewater discharges for 2005 are also presented. Wastewater discharge totals for 2005 are only presented for domestic facilities (municipal or privately owned). Wastewater discharge data for domestic self-supplied (through septic tanks), commercial-industrial self-supplied, agricultural selfsupplied and thermoelectric facilities were not available and are not included in this report.

The 2005 water-use data for the ACF River Basin were compiled at the county level. For each county that is partially within the basin, data were prorated and are presented for only that part of the basin. Data also are presented for the three basins (Apalachicola, Chattahoochee, and Flint) and by State (Alabama, Florida, and Georgia) (fig. 4). Withdrawal data are for freshwater only because no saline water withdrawals were identified within the basin in 2005.

Water-use trends within the ACF River Basin are described based on water-use data collected every 5 years from 1970 to 2005. Although some water-use data are presented for other years between 1971 and 2007 for Alabama, Florida, and Georgia, these data are not summarized, because they are often incomplete or subdivided by basin. Annual and monthly trends in public-supply water withdrawals and domestic wastewater discharge for 1970-2005 are presented where available. Estimates of annual and monthly water consumption are only presented for public supply within the basin; estimates of water consumption for the remaining four categories are not included.

\section{Previous Investigations}

This report is the second compilation by the U.S. Geological Survey on water withdrawal totals for the ACF River Basin. A previous report by Marella and others (1993) summarized water withdrawals and discharge for the basin for 1990 and presented trends in water use for the 1970-90 period.

Water-use data for the ACF River Basin for 1985 were compiled by the USGS and published in the proceedings of the 1991 Georgia Water Resources Conference (Marella, 1991, p. 9). These data were obtained from individual State reports for 1985 water use for Alabama (Baker and Mooty, 1987: Mooty, 1990), Florida (Bielby, 1987; Marella, 1988, 1990), and Georgia (Turlington and others, 1987; Pierce, 1990). Additional water-use reports are available for 


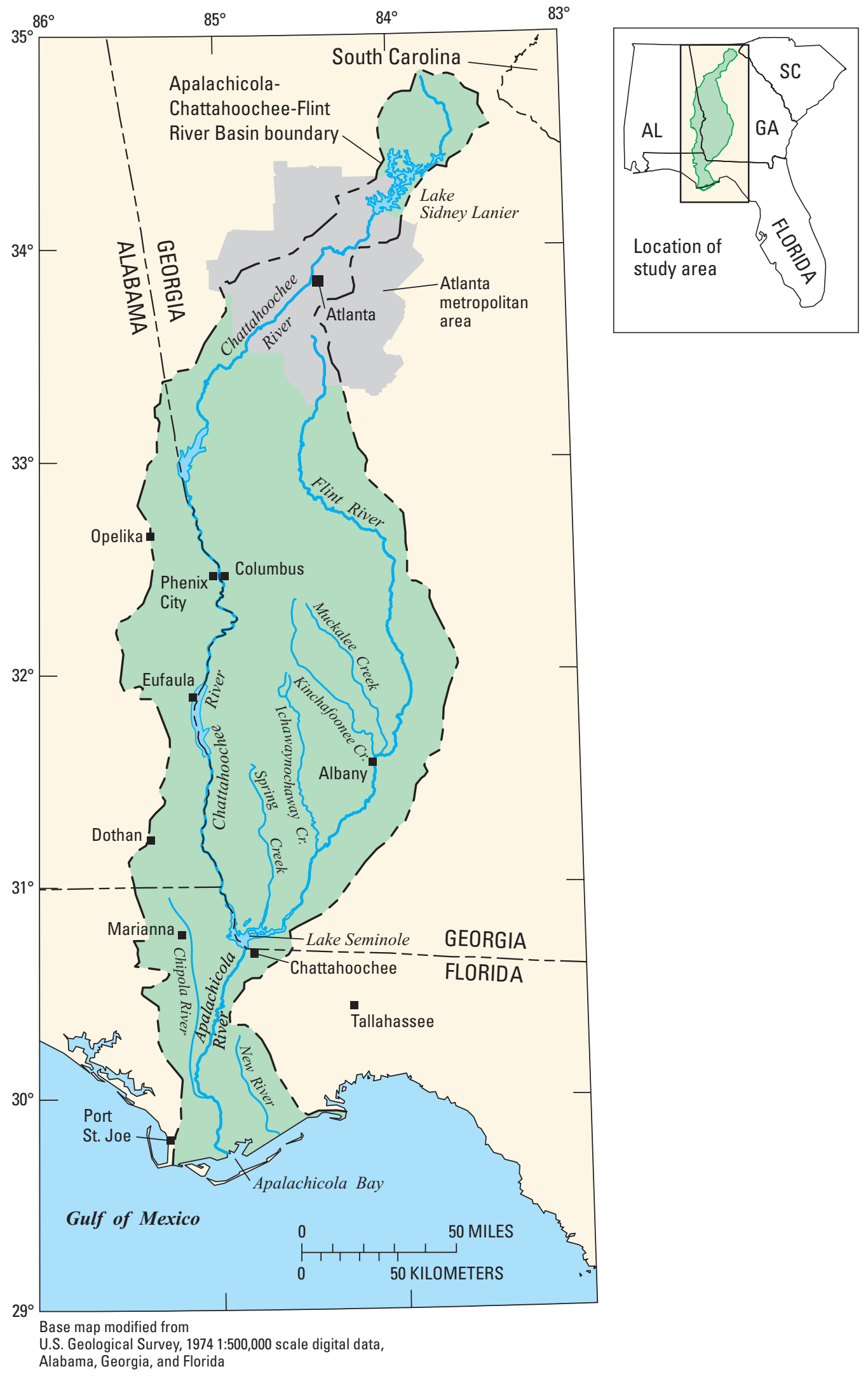

Figure 1. Location of the Apalachicola-Chattahoochee-Flint River Basin and selected cities. 


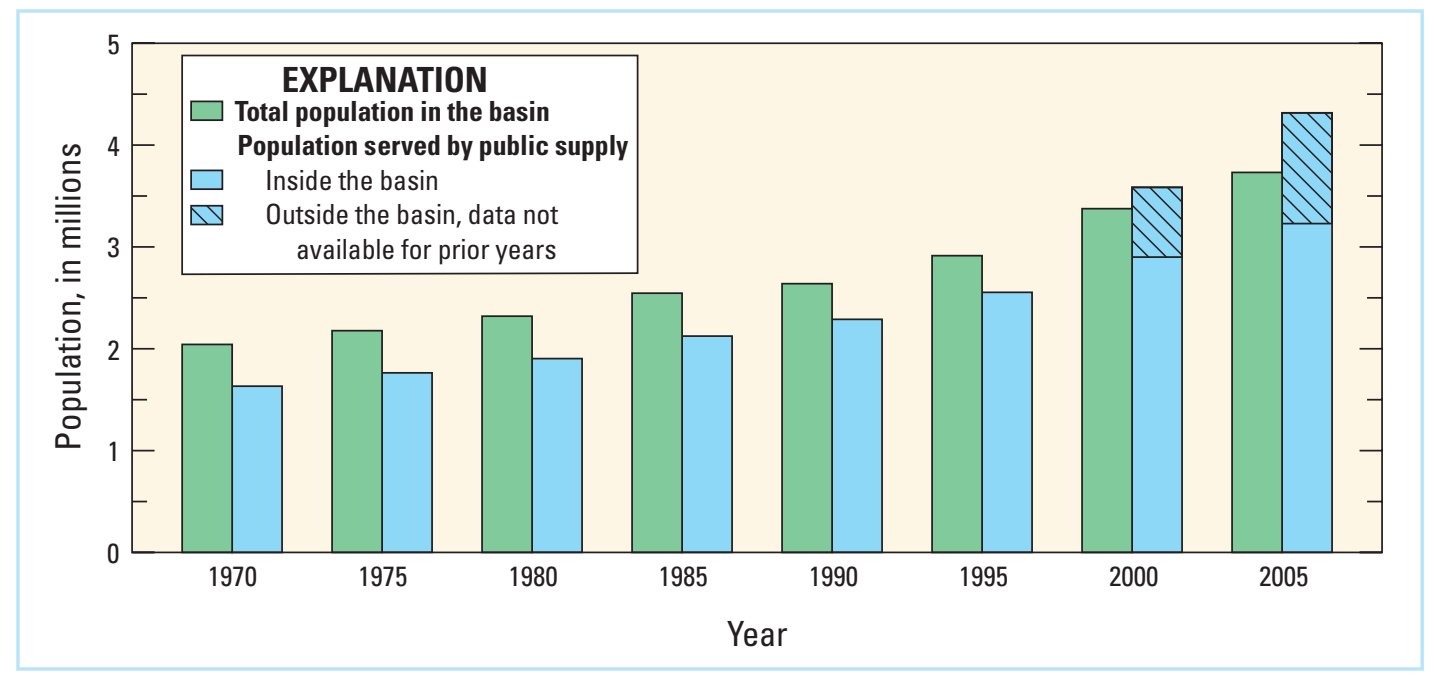

Figure 2. Total population and population served by public supply in the Apalachicola-ChattahoocheeFlint River Basin, 1970-2005.

Alabama, Florida, and Georgia for other years. Although most of these reports summarize water-use data by category and county, few provide totals by river basin.

In 1984, the U.S. Army Corps of Engineers completed an assessment of water resources in the ACF River Basin (U.S. Army Corps of Engineers, 1984). The study presented a complete basin inventory and reconnaissance of many aspects

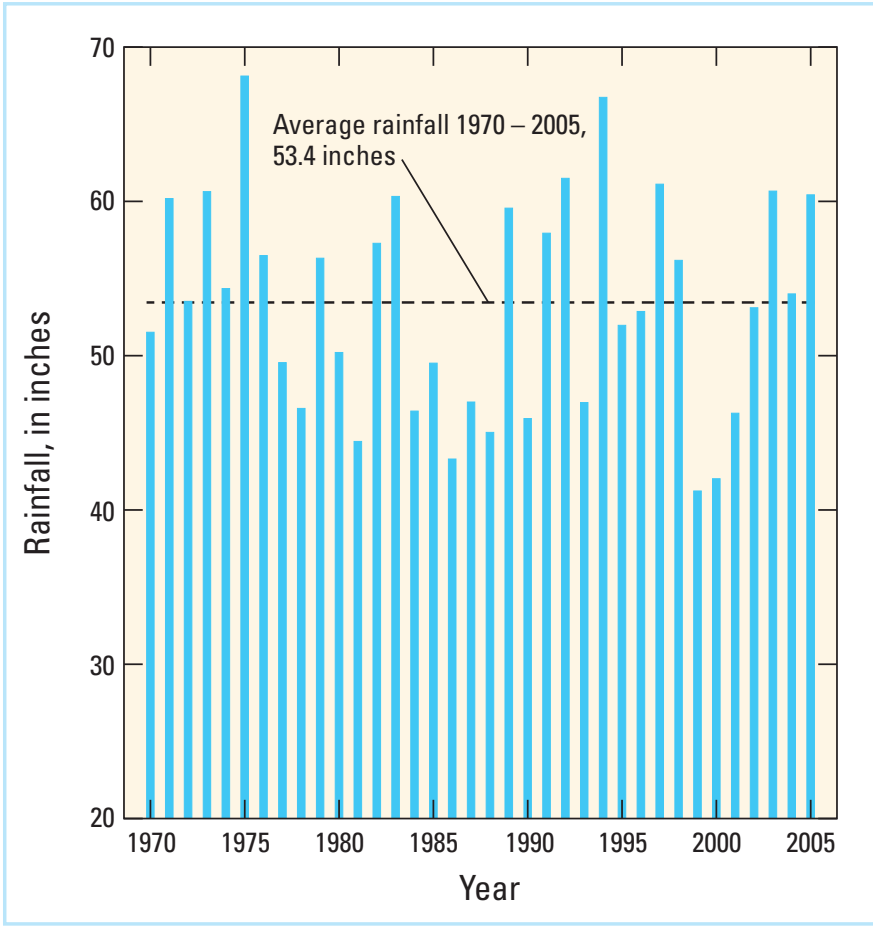

Figure 3. Annual and average rainfall in the ApalachicolaChattahoochee-Flint River Basin, 1970-2005. Modified from the U.S. Department of Commerce (2008). of water resources in the basin, including a description of 1980 water use. The Georgia Department of Natural Resources $(1984 a, b)$ reports provide a detailed inventory of water use and discharge in the Chattahoochee and Flint River Basins for 1982 and summarize data for 1980. Although many other studies have assessed water use for various parts of the ACF River Basin, few summarize water use for the entire basin.

\section{Data Sources and Accuracy}

As part of the USGS National Water-Use Information Program, water-use data are collected and compiled for each State every 5 years (Kenny and others, 2009). Data for 2005 in Alabama, Florida, and Georgia were collected through cooperative agreements with State governmental agencies using guidelines provided by the USGS (Hutson, 2007). Water-use data for each State is reported by major water-use category and county, with some States also reporting data by hydrologic unit (basin) and primary aquifer. In Alabama, water-use and wastewater discharge data were obtained in cooperation with the Office of Water Resources, Alabama Department of Economic and Community Affairs (ADECA). In Florida, water-use and wastewater discharge data were obtained in cooperation with the Florida Department of Environmental Protection and the Northwest Florida Water Management District (NWFWMD). In Georgia, water-use and wastewater discharge data were obtained through a cooperative effort with the Georgia Department of Natural Resources, Environmental Protection Division (GaEPD). Data sources for each specific category for Alabama, Florida, and Georgia are shown in table 1. More specific information for each category within each State is further detailed for Alabama in Hutson and others (2009), for Florida in Marella (2009), and for Georgia in Fanning and Trent (2009). 


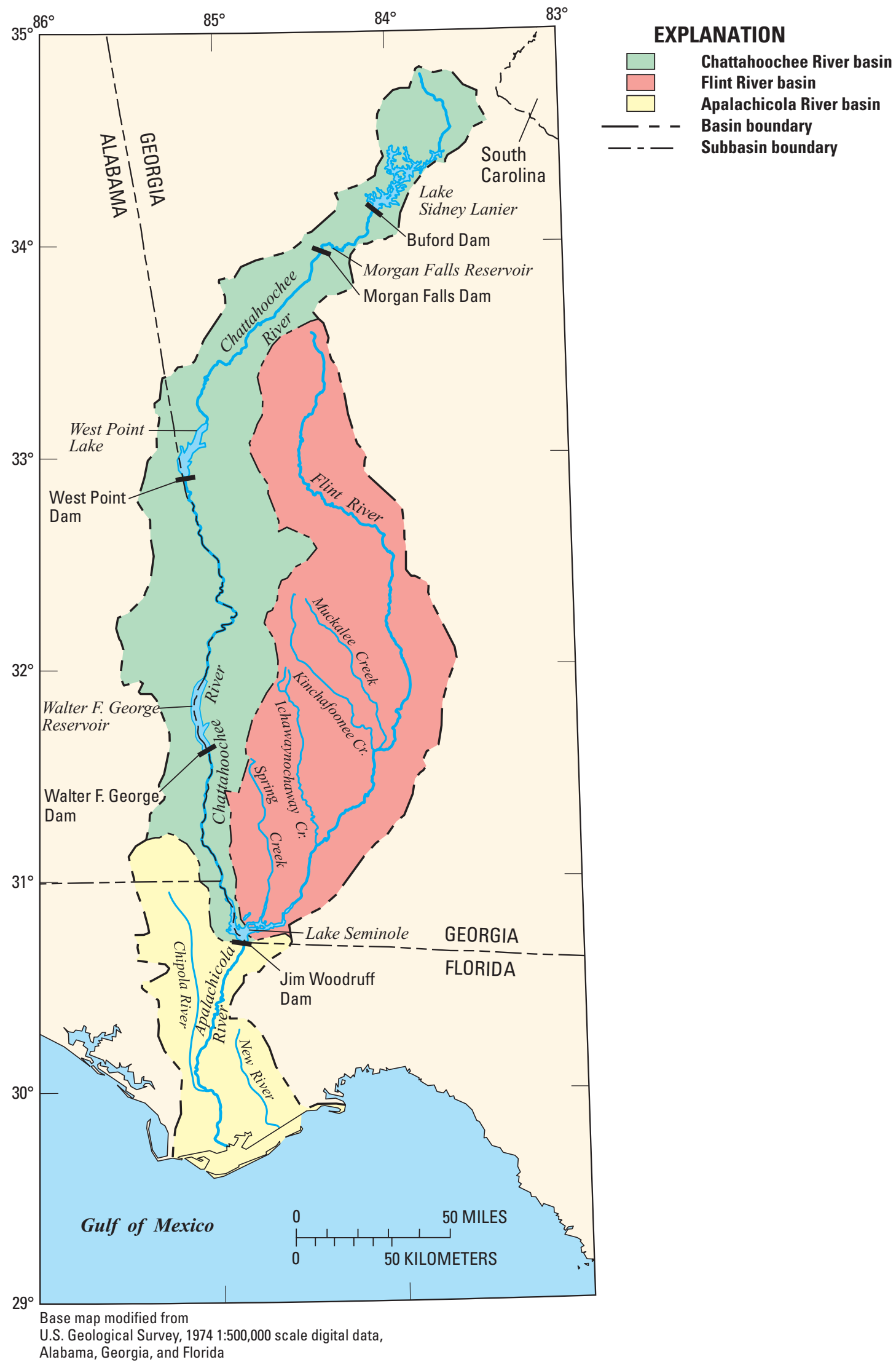

Figure 4. Location of major river basins within the Apalachicola-Chattahoochee-Flint River Basin. 
Table 1. Water-use data sources for Alabama, Florida, and Georgia, 2005.

[Modified from Fanning and Trent (2009), Hutson and others (2009), and Marella (2009)]

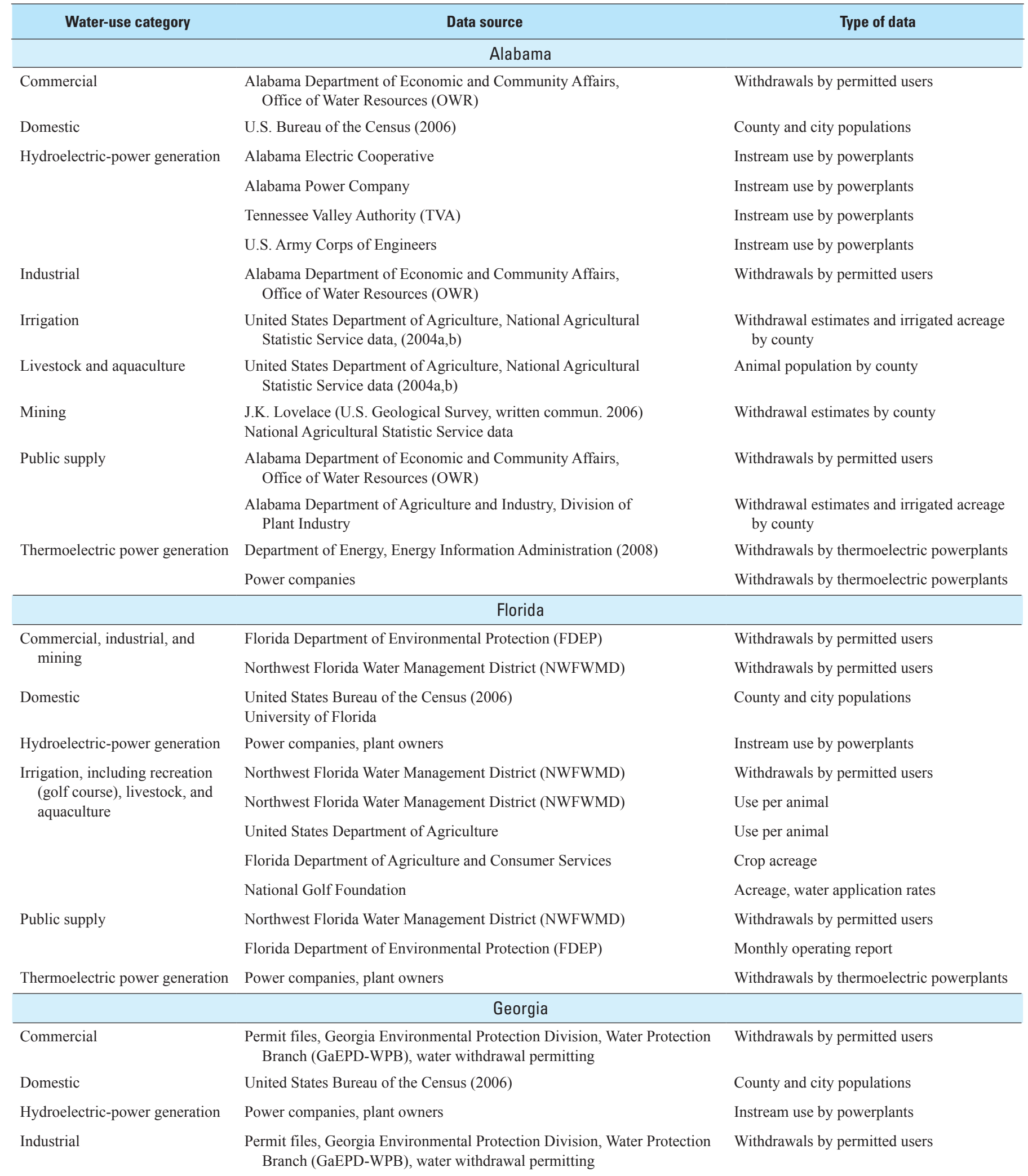


Table 1. Water-use data sources for Alabama, Florida, and Georgia, 2005. —Continued

[Modified from Fanning and Trent (2009), Hutson and others (2009), and Marella (2009)]

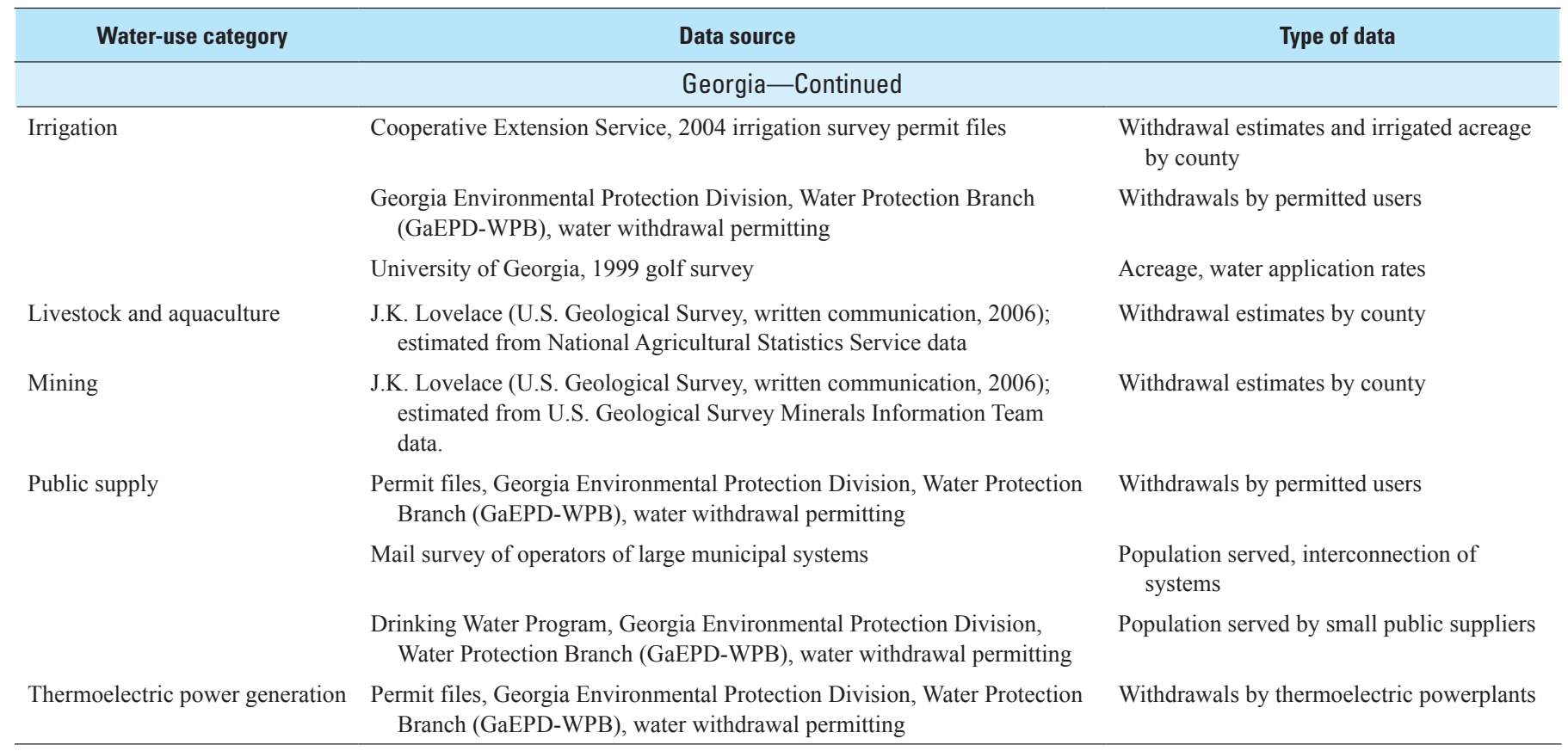

Water withdrawal and discharge data presented in this report represent average daily quantities either calculated from monthly totals or derived from annual totals, and are expressed in million gallons per day (Mgal/d). Water withdrawal and discharge values presented in the tables are reported to the nearest 10,000 gallons per day (gal/d) or to two places to the right of the decimal. Water withdrawal and discharge values in the text are rounded to the nearest million gallons per day, and percentages are rounded to whole numbers. Water withdrawal and discharge data published in this report and those published specifically for Alabama, Florida, or Georgia may not be identical because of differences in data-collection procedures, thresholds, categories, methodology, or rounding; in some cases the data may just be more recently revised.

The accuracy of water withdrawal values varies by category. Public-supply, commercial-industrial self-supplied and thermoelectric power generation values typically are more accurate, because most of the information obtained from these users consists of metered or permitted data. Because not all irrigators or private wells are metered, agricultural self-supplied and domestic self-supplied values typically are estimated based on several variables. Although a substantial number of irrigators within the ACF River Basin monitor their water withdrawals through metering programs in Florida and Georgia, these data are not used for the agricultural irrigation values presented herein because they are often not fully comprehensive. Wastewater discharge data presented in this report are obtained from metered records provided by each State regulator agency in charge of such records.

\section{Description of Study Area}

The ACF River Basin lies in southeastern Alabama, the central panhandle of northwestern Florida, and the northeastern, north-central, and southwestern parts of Georgia (fig. 1). The basin includes all or parts of 80 counties: 10 in Alabama, 8 in Florida, and 62 in Georgia (fig. 5). The southern and extreme northern parts of the basin are rural and predominantly consist of farmland, forest, and wetlands. In contrast, the north-central part of the basin is highly urbanized.

The ACF River Basin consists of three main rivers, the Chattahoochee, the Flint, and the Apalachicola (fig. 1), which collectively drain nearly $20,500 \mathrm{mi}^{2}$ (Seaber and others, 1984). The Chattahoochee River originates in the Blue Ridge physiographic province in northern Georgia above Lake Sidney Lanier, and flows 436 miles (mi) southwestward through the Piedmont and Coastal Plain physiographic provinces into Lake Seminole (Edmiston and Tuck, 1987). The corresponding drainage basin covers $8,800 \mathrm{mi}^{2}$ in Georgia, Florida, and Alabama (Seaber and others, 1984) (fig. 6). The Chattahoochee River flows through the urban areas of metropolitan Atlanta and Columbus, Ga. (fig. 1), and is impounded by four dams: Buford (forming Lake Sidney Lanier), Morgan Falls, Walter F. George, and West Point (fig. 4). The Flint River and its three main tributaries (Kinchafoonee-Muckalee, Ichawaynochaway, and Spring Creeks) drain about 8,500 $\mathrm{mi}^{2}$ (Seaber and others, 1984). The Flint River originates just south of Atlanta in 


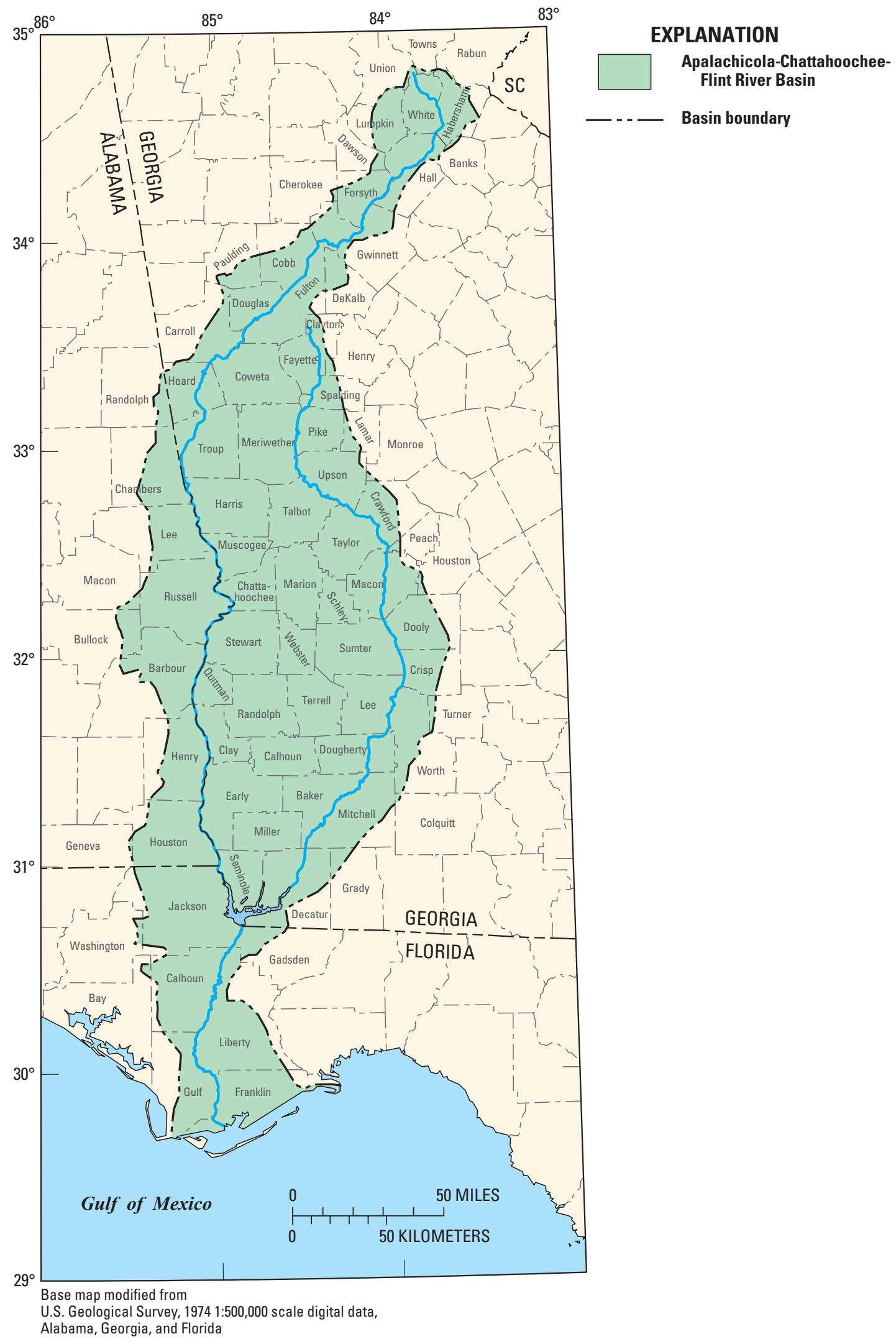

Figure 5. Location of counties within the Apalachicola-Chattahoochee-Flint River Basin. 


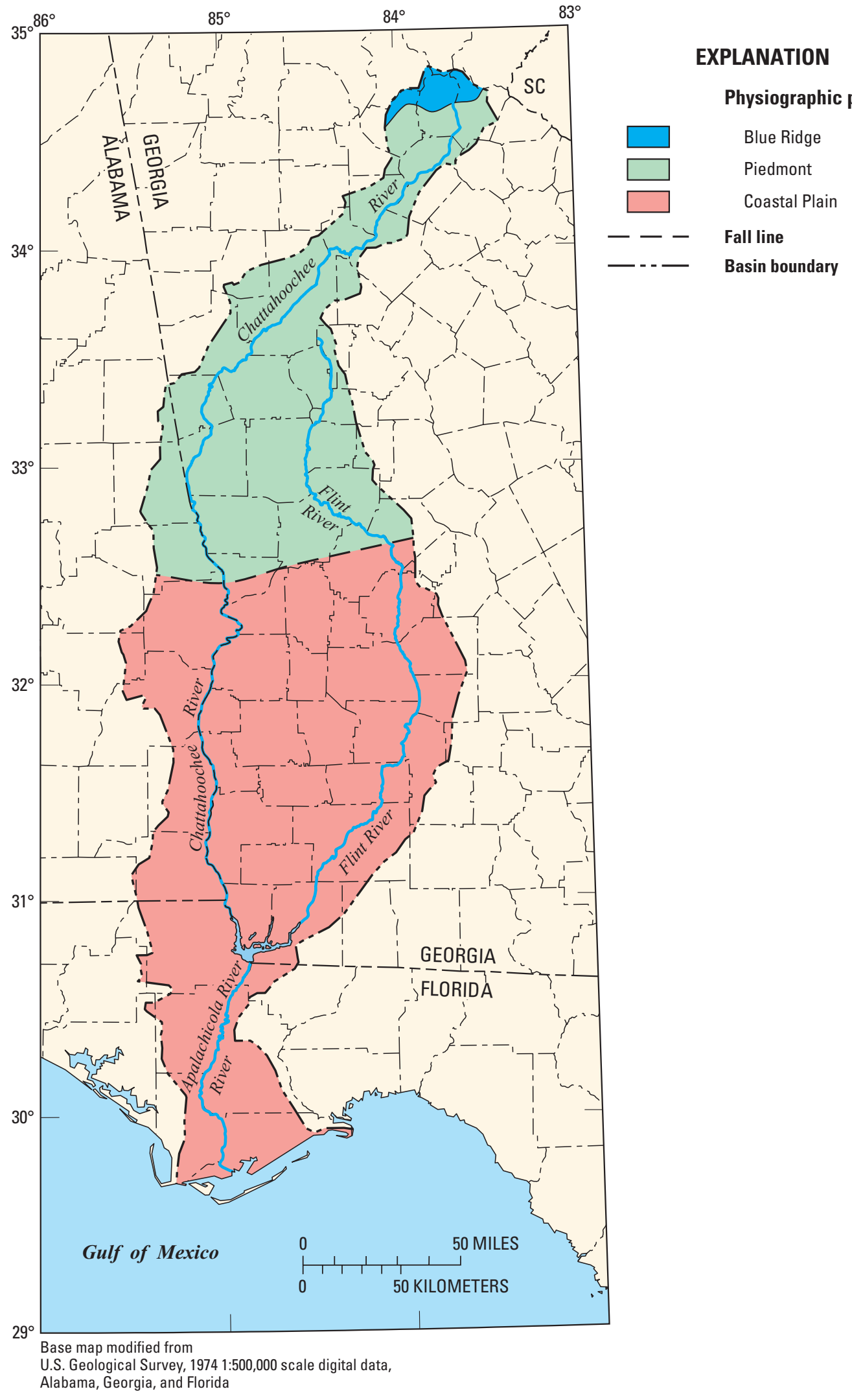

Figure 6. Location of physiographic provinces within the Apalachicola-Chattahoochee-Flint River Basin. Modified from Stringfield (1966, p. 6), Hayes and others (1983), and Clark and Pierce (1985). 
the Piedmont physiographic province and flows $350 \mathrm{mi}$ (Edmiston and Tuck, 1987) southward through the agricultural areas in the Coastal Plain of southwestern Georgia (fig. 6). The Apalachicola River is formed by the confluence of the Chattahoochee and Flint Rivers at the Jim Woodruff Dam and Lake Seminole (fig. 4). Located in the Coastal Plain physiographic province (fig. 6), the Apalachicola River and its main tributary, the Chipola River, drain nearly 2,500 $\mathrm{mi}^{2}$ (Seaber and others, 1984) of Alabama and Florida. The remaining area of the basin lies along the coast and wetlands of the Gulf of Mexico in Apalachicola Bay and the New River (Seaber and others, 1984). The Floridan aquifer system underlies the southern part of the basin and is the primary water source in Florida and southwestern Georgia (fig. 7). Other less productive groundwater sources within the basin include the Clairborne and Clayton aquifers, the Cretaceous aquifer system, and crystalline rock aquifers (Clarke and Pierce, 1985) (fig. 7).

\section{Estimated Water Withdrawals, 2005}

The total amount of water withdrawn in the ACF River Basin in 2005 was estimated to be $1,990 \mathrm{Mgal} / \mathrm{d}$, and was all freshwater. Surface water and groundwater, respectively, accounted for 1,591 Mgal/d (80 percent) and $399 \mathrm{Mgal} / \mathrm{d}$ (20 percent) of the total water withdrawn (fig. 8 and table 2). Because of the location and availability of the water resources in the basin, surface water accounts for the majority of water withdrawn in the northern and central parts of the basin, whereas groundwater is the primary water source in the southern areas where it is more readily available. The Chattahoochee River subbasin accounted for the largest percentage of the total withdrawals (66 percent), followed by the Flint River subbasin (27 percent), and the Apalachicola River subbasin (7 percent). Among the three States represented in the ACF River Basin, Georgia accounted for the largest percentage of the total water withdrawn (84 percent), followed by Alabama ( 9 percent), and Florida ( 7 percent). Water withdrawn by category is shown by major river basin in table 3 and figure $9 A$, and by State in table 4 and figure $9 B$.

\section{Total Water Withdrawals by Category, 2005}

Thermoelectric power generation accounted for the largest percentage of water withdrawn, composing $788 \mathrm{Mgal} / \mathrm{d}$ (40 percent) of the total for all categories; however, most of the use was nonconsumptive. Nearly all of the water withdrawn for thermoelectric power was used for once-through cooling and returned to its source. Water used for public supply accounted for about $609 \mathrm{Mgal} / \mathrm{d}$ (30 percent) of the total water withdrawn, followed by agricultural self-supplied (including crop and golf course irrigation and livestock) at $365 \mathrm{Mgal} / \mathrm{d}$ (18 percent), commercial-industrial self-supplied (including mining) at $191 \mathrm{Mgal} / \mathrm{d}$ (10 percent), and domestic self-supplied at $37 \mathrm{Mgal} / \mathrm{d}$ (2 percent; fig. 8 and table 2). Excluding withdrawals for thermoelectric power generation, water used for public supply accounted for 51 percent of the total water withdrawn.

By category, the following counties had the largest withdrawals: Cobb County, Ga. (thermoelectric power generation, $363 \mathrm{Mgal} / \mathrm{d}$ ); Fulton County, Ga. (public supply, $154 \mathrm{Mgal} / \mathrm{d}$ ); Seminole County, Ga. (agricultural self-supplied, $38 \mathrm{Mgal} / \mathrm{d}$ ); Early County, Ga. (commercial-industrial selfsupplied, $108 \mathrm{Mgal} / \mathrm{d}$ ), and Douglas County, Ga. (domestic self-supplied, $3 \mathrm{Mgal} / \mathrm{d}$; table 5).

In 2005, most of the surface water withdrawn was for thermoelectric power generation (50 percent) and public supply (34 percent), whereas most of the groundwater withdrawn (66 percent) was for agricultural self-supplied use (table 2). Surface-water withdrawals were largest in Cobb County, Ga. (410 Mgal/d; table 5). For the same year, the Chattahoochee River was the largest supplier of surface water in the basin. The largest amount of groundwater withdrawn in 2005 was in Dougherty County, Ga. (38 Mgal/d; table 5); the Floridan aquifer system (as shown in fig. 7) was the primary source of groundwater in the basin for this year.

\section{Public Supply}

The public-supply category refers to water withdrawn or purchased then distributed by a publicly (municipal) or privately owned community water system to the public for human consumption (see Glossary). Community water systems serve at least 15 service connections or at least 25 year-round residents. Public supply totals do not include noncommunity public-water systems that serve transient populations, such as churches, restaurants, theme parks, and others that provide drinking water to a nonpermanent population. Estimates of the total population served for this category also were made by each State for nearly all water systems in 2005 (Fanning and Trent, 2009; Hutson and others, 2009; Marella, 2009).

Water withdrawals for public supply totaled $609 \mathrm{Mgal} / \mathrm{d}$ (table 2), of which surface water totaled $545 \mathrm{Mgal} / \mathrm{d}$ (89 percent) and groundwater totaled $64 \mathrm{Mgal} / \mathrm{d}$ (11 percent). Of all counties in the ACF River Basin, surface-water withdrawals for public supply use in 2005 were largest in Fulton County, Ga. (154 Mgal/d), followed by Gwinnett County, Ga. (87 Mgal/d) and DeKalb County, Ga. (83 Mgal/d; table 5). These three counties accounted for nearly 60 percent of the surface-water withdrawals used for public supply in the basin during 2005. Some of the water withdrawn in the basin in Cobb, Gwinnett, and DeKalb Counties, Ga., is used for public-supply outside of the basin. Overall, the eight metropolitan Atlanta counties of Georgia (Clayton, Cobb, DeKalb, Douglas, Fayette, Fulton, Gwinnett, and Henry) accounted for 68 percent of the public-supply withdrawals, which were mostly from surface-water sources. Groundwater was the largest source of water withdrawn for public supply in Dougherty County, Ga. (14 Mgal/d; table 5). 


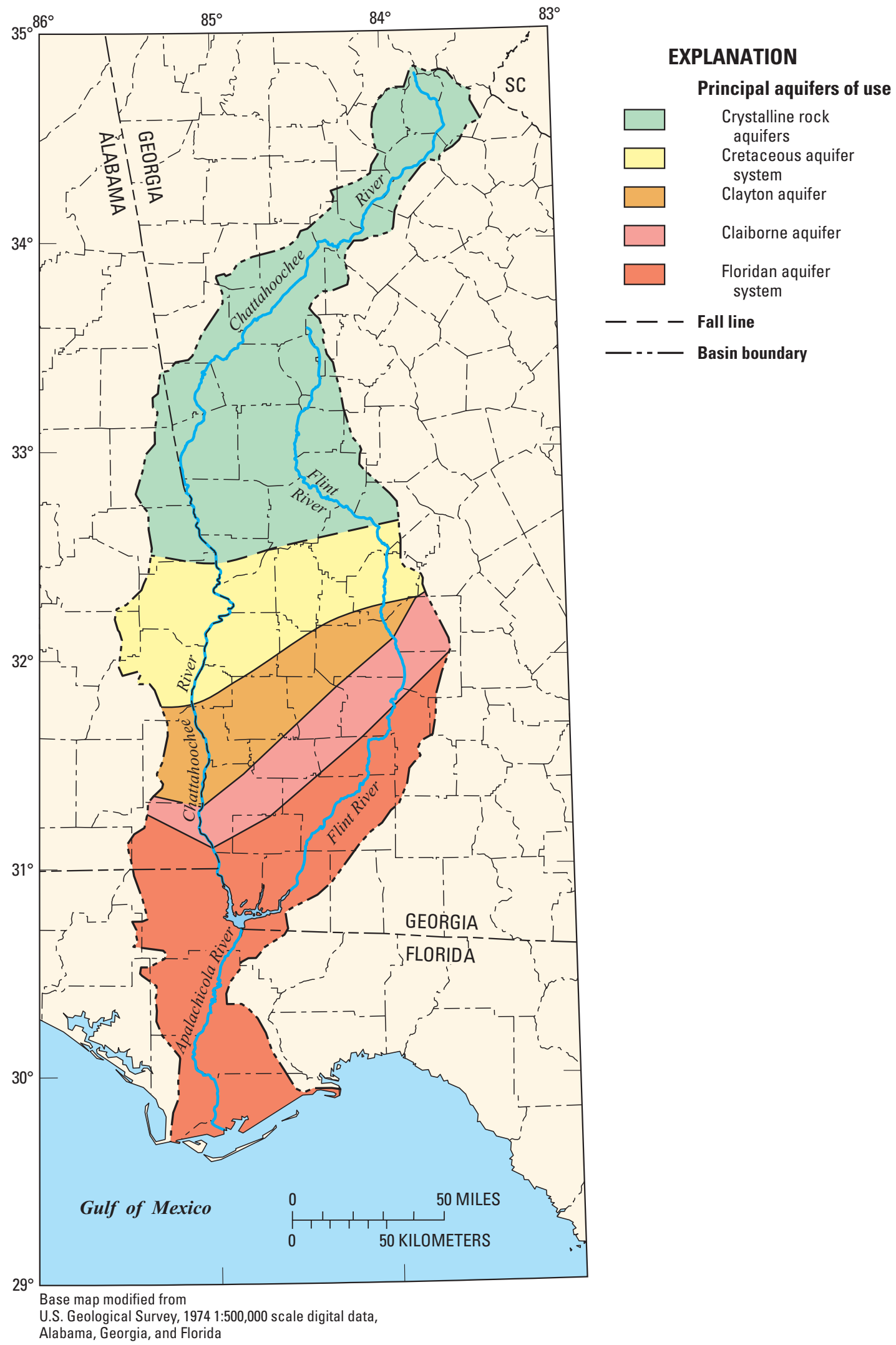

Figure 7. General location of principal aquifers used within the Apalachicola-Chattahoochee-Flint River Basin. Modified from Clark and Pierce (1985). 


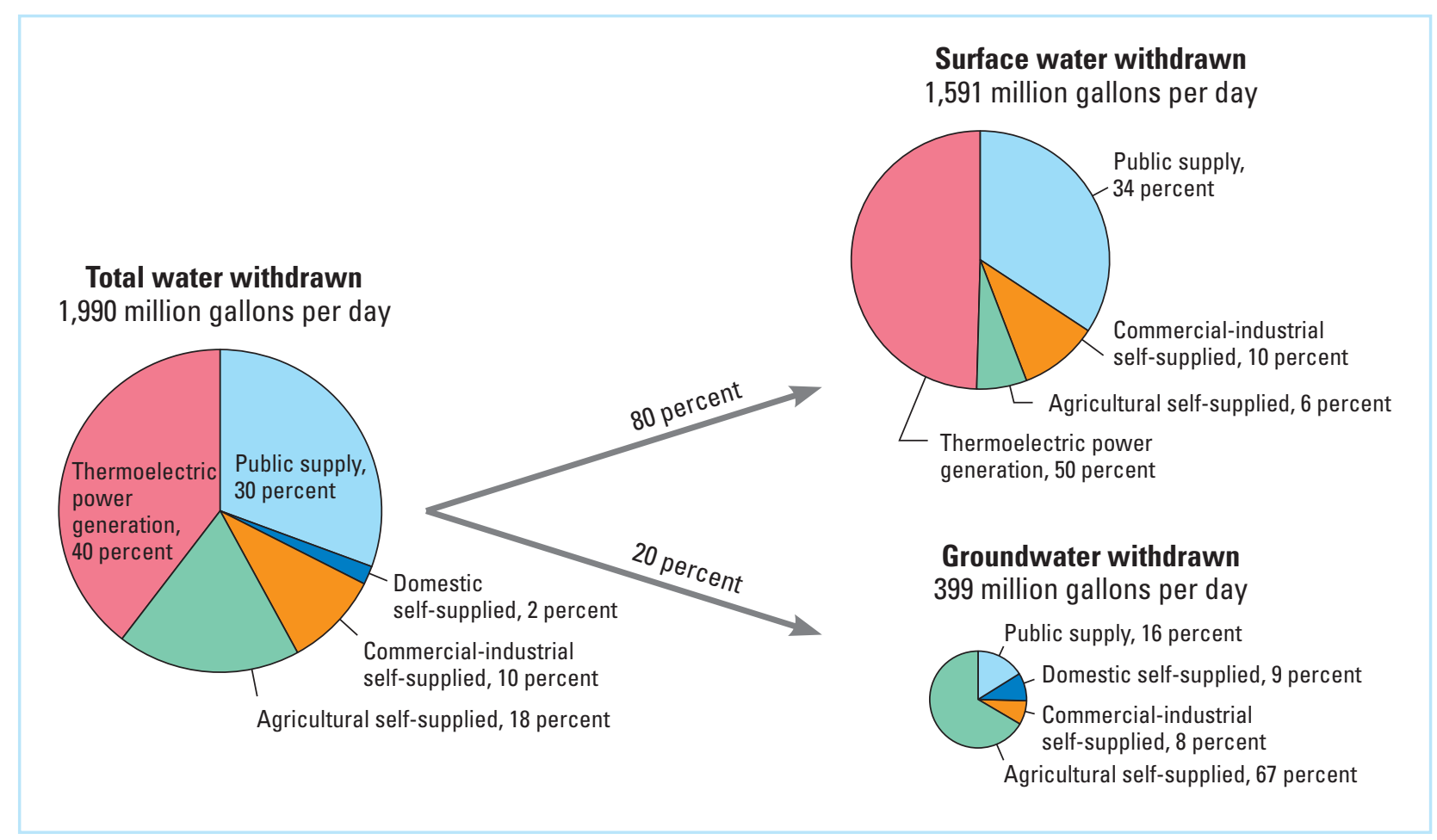

Figure 8. Water withdrawals in the Apalachicola-Chattahoochee-Flint River Basin, 2005.

Table 2. Total water withdrawals by category in the Apalachicola-Chattahoochee-Flint River Basin, 2005.

[Compiled by the U.S. Geological Survey. All values are in million gallons per day]

\begin{tabular}{lrrr}
\hline \multirow{2}{*}{ Category } & \multicolumn{3}{c}{ Freshwater withdrawals } \\
\cline { 2 - 4 } & Ground & Surface & \multicolumn{1}{c}{ Total } \\
\hline Public supply & 64.17 & 544.67 & 608.84 \\
$\begin{array}{l}\text { Domestic self-supplied } \\
\text { Commercial-industrial } \\
\text { self-supplied }\end{array}$ & 37.25 & 0.00 & 37.25 \\
$\begin{array}{l}\text { Agricultural self-supplied } \\
\text { (2) }\end{array}$ & 32.10 & 158.50 & 190.60 \\
$\begin{array}{l}\text { Thermoelectric power } \\
\text { generation }\end{array}$ & 264.63 & 100.25 & 364.88 \\
\hline Basin totals & 0.48 & 787.84 & 788.32 \\
\hline
\end{tabular}

${ }^{1}$ Commercial-industrial self-supplied includes withdrawals for mining operations.

${ }^{2}$ Agricultural self-supplied includes water withdrawn for crop irrigation, aquaculture, livestock, and golf course irrigation.
In 2005, water withdrawn for public-supply use provided drinking water to nearly 4.317 million people (fig. 2); however, not all of these people resided within the ACF River Basin. An estimated 1.080 million people were located outside of the basin but obtained their public-supply water from a withdrawal source within the basin, mostly in the metropolitan Atlanta area. Overall, 3.237 million people (4.317 minus 1.080) within the basin obtained their water from a public-supply water system in 2005 . About 87 percent (3.775 million) of the total population served obtained their public-supply drinking water from surface-water sources in 2005 , whereas the remaining 13 percent $(0.542$ million people) obtained their drinking water from groundwater sources. The public-supply per capita water use was estimated to be $141 \mathrm{gal} / \mathrm{d}$ for the basin in 2005 . This value is the total public-supply water withdrawn (609 Mgal/d) divided by the total population served by public supply (4.317 million). Per capita water use computed by this method includes water provided to all uses of public-supplied water (including domestic or household, commercial, industrial, and other uses) and losses (Marella, 2009). 
Table 3. Total water withdrawals by category in the ApalachicolaChattahoochee-Flint River Basin by major river basin, 2005

[Compiled by the U.S. Geological Survey and modified from Fanning and Trent (2009), Hutson and others (2009), and Marella (2009). All values are in million gallons per day]

\begin{tabular}{|c|c|c|c|}
\hline \multirow{2}{*}{ Category } & \multicolumn{2}{|c|}{ Fresh } & \multirow{2}{*}{$\begin{array}{c}\text { Total } \\
\text { freshwater }\end{array}$} \\
\hline & Ground & Surface & \\
\hline \multicolumn{4}{|c|}{ Apalachicola } \\
\hline Public supply & 7.31 & 0.00 & 7.31 \\
\hline Domestic self-supplied & 4.06 & 0.00 & 4.06 \\
\hline Commercial-industrial self-supplied ${ }^{1}$ & 2.41 & 0.00 & 2.41 \\
\hline Agricultural self-supplied ${ }^{2}$ & 17.25 & 5.36 & 22.61 \\
\hline Thermoelectric power generation & 0.26 & 102.44 & 102.70 \\
\hline Total & 31.29 & 107.80 & 139.09 \\
\hline \multicolumn{4}{|c|}{ Chattahoochee } \\
\hline Public supply & 14.93 & 497.43 & 512.36 \\
\hline Domestic self-supplied & 19.40 & 0.00 & 19.40 \\
\hline Commercial-industrial self-supplied ${ }^{1}$ & 11.52 & 146.77 & 158.29 \\
\hline Agricultural self-supplied ${ }^{2}$ & 27.04 & 33.97 & 61.01 \\
\hline Thermoelectric power generation & 0.17 & 564.55 & 564.72 \\
\hline Total & 73.06 & $1,242.72$ & $1,315.78$ \\
\hline \multicolumn{4}{|c|}{ Flint } \\
\hline Public supply & 41.93 & 47.24 & 89.17 \\
\hline Domestic self-supplied & 13.79 & 0.00 & 13.79 \\
\hline Commercial-industrial self-supplied ${ }^{1}$ & 18.17 & 11.73 & 29.90 \\
\hline Agricultural self-supplied ${ }^{2}$ & 220.34 & 60.92 & 281.26 \\
\hline Thermoelectric power generation & 0.05 & 120.85 & 120.90 \\
\hline Total & 294.28 & 240.74 & 535.02 \\
\hline Basin totals & 398.63 & $1,591.26$ & $1,989.89$ \\
\hline
\end{tabular}

${ }^{1}$ Commercial-industrial self-supplied includes withdrawals for mining operations.

${ }^{2}$ Agricultural self-supplied includes water withdrawn for crop irrigation, aquaculture, livestock, and golf course irrigation.

\section{Domestic Self-Supplied}

The domestic self-supplied category includes potable water withdrawn in relatively small quantities and used mainly for drinking purposes, but also includes outdoor uses such as lawn irrigation and pool replenishing. Domestic self-supplied use includes water withdrawals from individual domestic or private wells that serve a household (in some cases, multiple households) or by small public-supply systems (with a daily average pumpage of less than $0.01 \mathrm{Mgal} / \mathrm{d}$ ) not inventoried under the public-supply category. In 2005, nearly half a million people (0.496, or 13 percent of the ACF River Basin population) were considered self-supplied, because they were not served by an inventoried public supplier. Domestic self-supplied populations were derived by subtracting the population served by the public-supply systems from the total population in each county. 


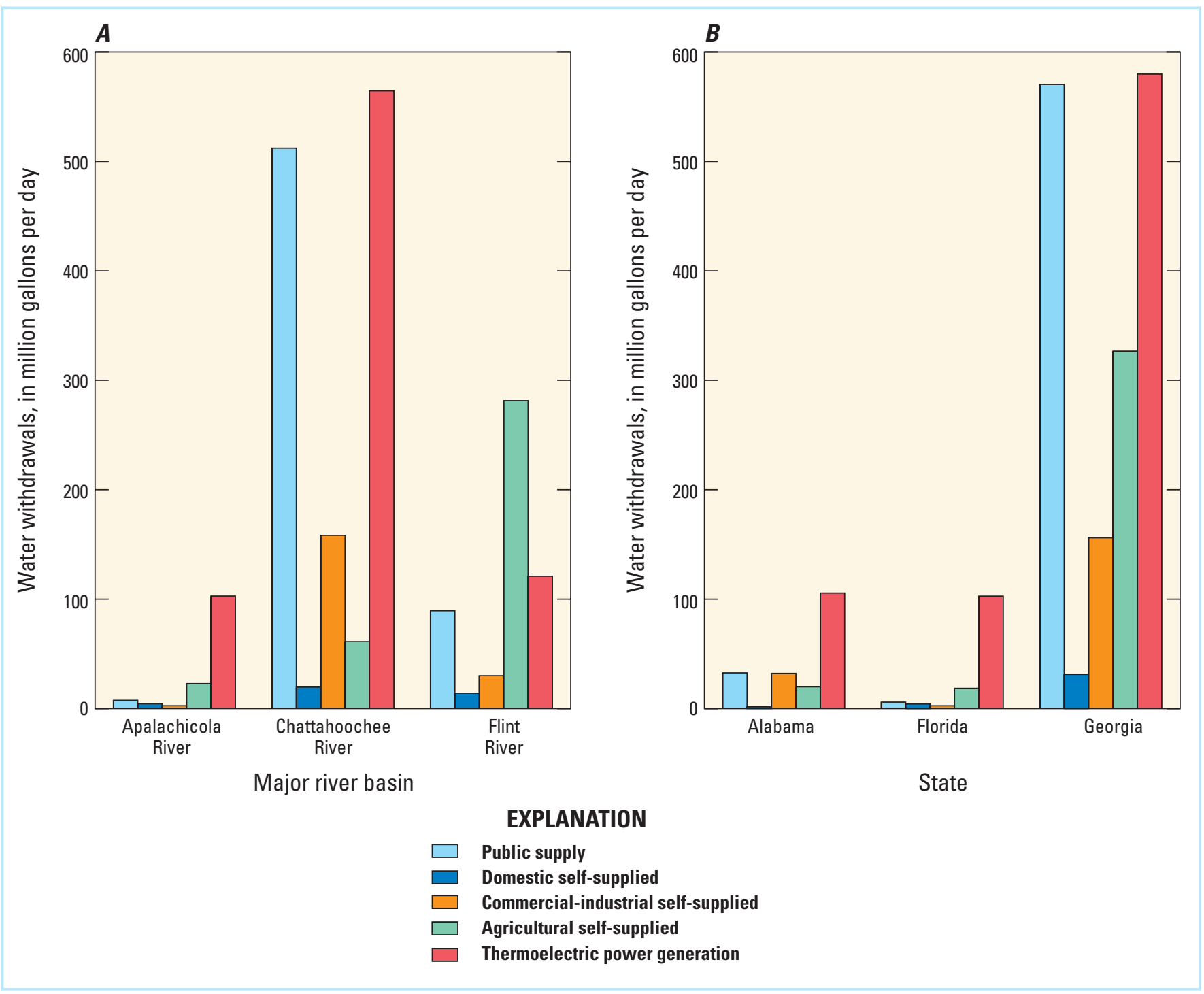

Figure 9. Water withdrawals by category in the Apalachicola-Chattahoochee-Flint River Basin, 2005 by $A$, major river basin, and $B$, State.

Domestic self-supplied water withdrawals in the ACF River Basin are assumed to be obtained from groundwater sources only. In 2005, groundwater withdrawn for domestic self-supplied use in the basin totaled $37 \mathrm{Mgal} / \mathrm{d}$ (table 2). Douglas County, Ga., which is entirely within the ACF River Basin, accounted for the largest amount of water withdrawn for domestic self-supplied use in 2005 (3 Mgal/d; table 5). Domestic self-supplied withdrawals are calculated using the self-supplied population in each county multiplied by a per capita water-use coefficient, estimated to be $95 \mathrm{gal} / \mathrm{d}$ in Florida (Marella, 2009) and $75 \mathrm{gal} / \mathrm{d}$ in Alabama (Hutson and others, 2009) and Georgia (Fanning and Trent, 2009).

\section{Commercial-Industrial Self-Supplied}

Commercial-industrial self-supplied use refers to water withdrawn directly by commercial and industrial facilities (see Glossary). Commercial users include government and military facilities, schools, prisons, hospitals, recreational, and nonmanufacturing facilities. Industrial users include processing and manufacturing facilities. This category also includes water withdrawn for all mining operations, including processing, washing, dust control, and dewatering. 
Table 4. Total water withdrawals by category in the ApalachicolaChattahoochee-Flint River Basin by state, 2005

[Compiled by the U.S. Geological Survey and modified from Fanning and Trent (2009), Hutson and others (2009), and Marella (2009). All values are in million gallons per day]

\begin{tabular}{|c|c|c|c|}
\hline \multirow{2}{*}{ Category } & \multicolumn{2}{|c|}{ Fresh } & \multirow{2}{*}{$\begin{array}{c}\text { Total } \\
\text { freshwater }\end{array}$} \\
\hline & Ground & Surface & \\
\hline \multicolumn{4}{|c|}{ Alabama } \\
\hline Public supply & 13.48 & 18.92 & 32.40 \\
\hline Domestic self-supplied & 1.71 & 0.00 & 1.71 \\
\hline Commercial-industrial self-supplied ${ }^{1}$ & 2.35 & 29.76 & 32.11 \\
\hline Agricultural self-supplied ${ }^{2}$ & 7.78 & 11.91 & 19.69 \\
\hline Thermoelectric power generation & 0.17 & 105.36 & 105.53 \\
\hline Total & 25.49 & 165.95 & 191.44 \\
\hline \multicolumn{4}{|c|}{ Florida } \\
\hline Public supply & 5.67 & 0.00 & 5.67 \\
\hline Domestic self-supplied & 4.23 & 0.00 & 4.23 \\
\hline Commercial-industrial self-supplied ${ }^{1}$ & 2.41 & 0.00 & 2.41 \\
\hline Agricultural self-supplied ${ }^{2}$ & 13.92 & 4.60 & 18.52 \\
\hline Thermoelectric power generation & 0.26 & 102.44 & 102.70 \\
\hline Total & 26.49 & 107.04 & 133.53 \\
\hline \multicolumn{4}{|c|}{ Georgia } \\
\hline Public supply & 45.02 & 525.75 & 570.77 \\
\hline Domestic self-supplied & 31.31 & 0.00 & 31.31 \\
\hline Commercial-industrial self-supplied ${ }^{1}$ & 27.34 & 128.74 & 156.08 \\
\hline Agricultural self-supplied ${ }^{2}$ & 242.93 & 83.74 & 326.67 \\
\hline Thermoelectric power generation & 0.05 & 580.04 & 580.09 \\
\hline Total & 346.65 & $1,318.27$ & $1,664.92$ \\
\hline Basin totals & 398.63 & $1,591.26$ & $1,989.89$ \\
\hline
\end{tabular}

${ }^{1}$ Commercial-industrial self-supplied includes withdrawals for mining operations.

${ }^{2}$ Agricultural self-supplied includes water withdrawn for crop irrigation, aquaculture, livestock, and golf course irrigation.

In 2005, withdrawals for commercial-industrial self-supplied systems totaled $191 \mathrm{Mgal} / \mathrm{d}$ (table 2), $159 \mathrm{Mgal} / \mathrm{d}$ (83 percent) from surface-water sources and $32 \mathrm{Mgal} / \mathrm{d}$ (17 percent) from groundwater sources. Early County, Ga., accounted for the largest amount of surface-water withdrawals (107 Mgal/d), whereas Dougherty County, Ga., accounted for largest amount of groundwater withdrawals (14 Mgal/d; table 5). The majority of water withdrawals in this category were for industrial purposes (88 percent), whereas commercial and mining withdrawals accounted for 6 percent each. In addition to self-supplied water withdrawals, most commercial and many industrial facilities within the ACF River Basin obtained water from public-supply water systems, and their usage is accounted for under public-supply withdrawals.

\section{Agricultural Self-Supplied (Irrigation and Nonirrigation)}

Agricultural self-supplied use refers to water withdrawals for crop irrigation and for nonirrigation uses associated with farming (see Glossary). Crop irrigation includes the application of water on lands to assist in the growing of crops or to prevent damage to crops because of harsh climatic conditions. Nonirrigation uses include withdrawals for livestock watering, washing of dairy and farm equipment, fish farming (pond replenishment), and other farm uses. For this report, the agricultural self-supplied category also includes water withdrawals for turf grass irrigation at golf courses. 


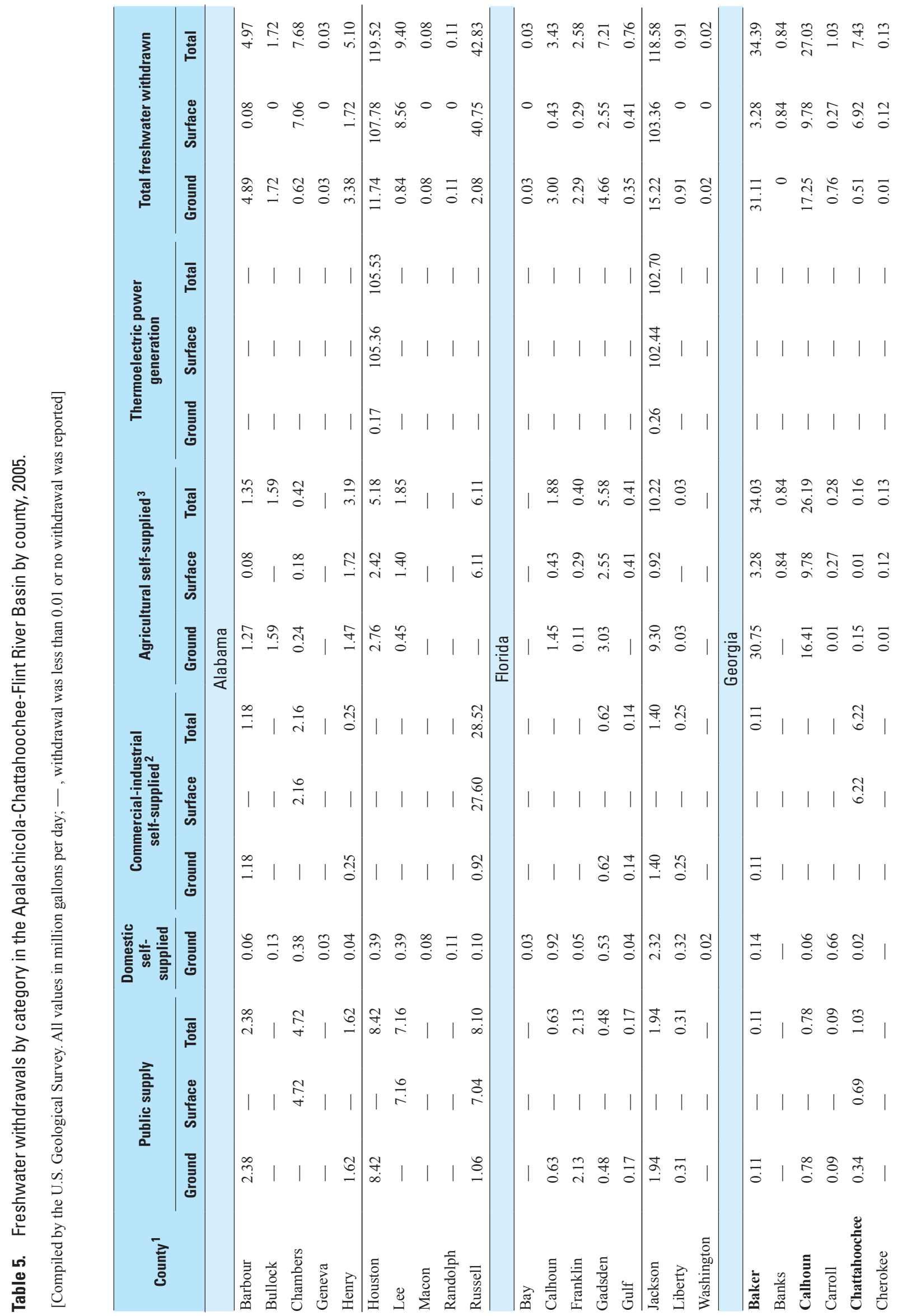




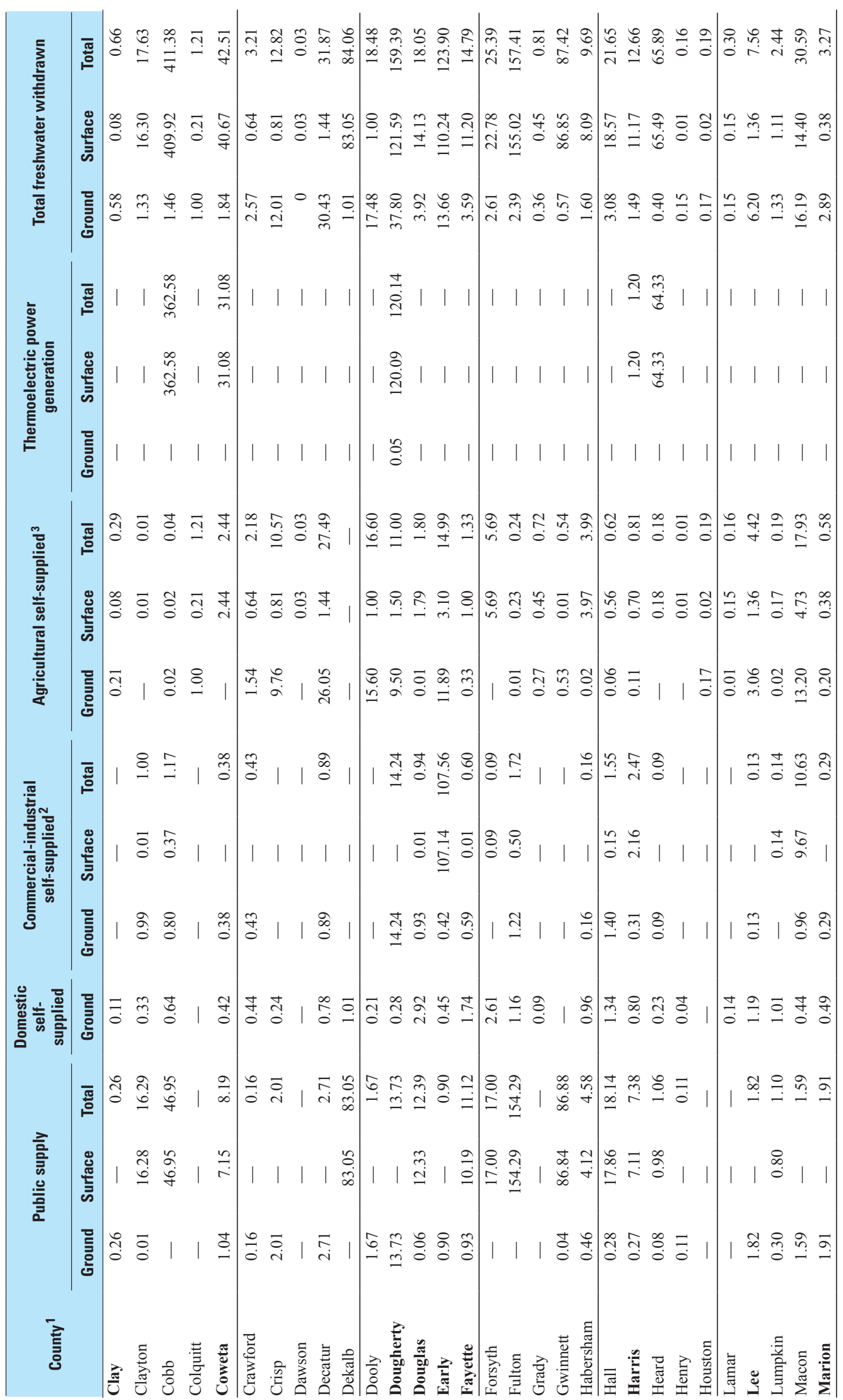




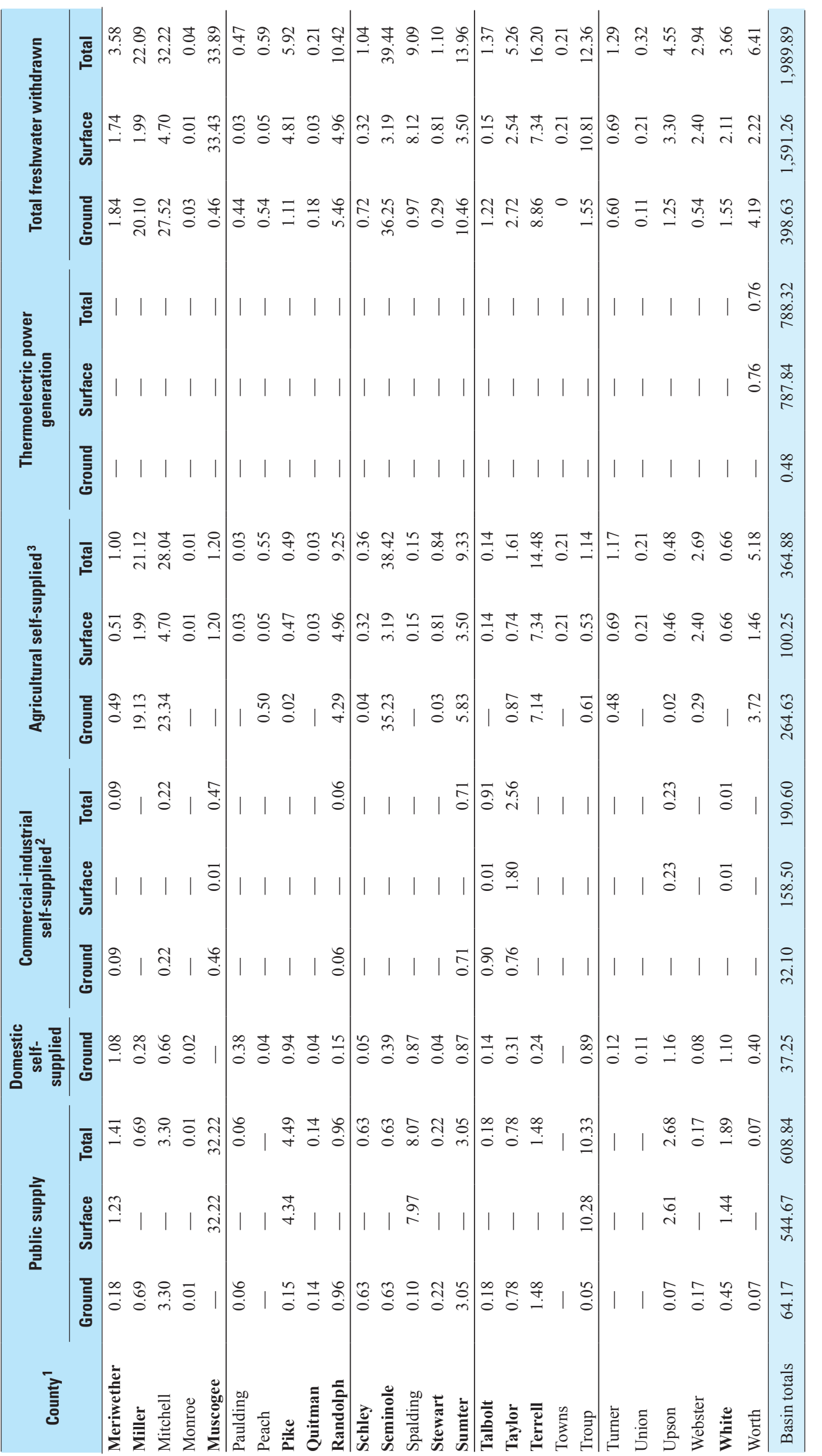


Water withdrawals for agricultural self-supplied use in the ACF River Basin in 2005 totaled $365 \mathrm{Mgal} / \mathrm{d}$ (table 2). Groundwater supplied about 73 percent $(265 \mathrm{Mgal} / \mathrm{d})$ of the total, whereas surface water supplied about 27 percent (100 Mgal/d). Seminole County, Ga., accounted for the largest amount of groundwater withdrawals (35 Mgal/d), followed by Baker County, Ga. (31 Mgal/d). Calhoun County, Ga., accounted for the largest amount of surface-water withdrawals (10 Mgal/d; table 5). A substantial amount of surface-water withdrawals for this category is obtained from onsite farm ponds, many augmented by groundwater wells.

Overall, water used for crop irrigation accounted for about 98 percent of the water withdrawn in this category, with the remaining 2 percent withdrawn for golf course irrigation and nonirrigation uses (primarily livestock watering and fish farming) in 2005. Some water used for golf course irrigation in the basin is accounted for in the commercial-industrial selfsupplied category, but was not substantially significant.

Because not all irrigators within the basin monitor their water withdrawals through metering or permit compliance programs, values for this category were estimated using coefficients. Water-withdrawal values for agricultural self-supplied are calculated based on crop acreage data and net irrigation coefficients. Crop acreage data were obtained from multiple sources, but generally were obtained from the U.S. Department of Agriculture, the State Agricultural Statistic Services, or the County Extension Offices in all three States. Net irrigation coefficients generally were provided by the local or State permitting agencies, the University Agricultural Research Centers, or from other sources.

\section{Thermoelectric Power Generation}

Thermoelectric power generation use includes water withdrawn at fossil fuel (coal, gas, or oil) or nuclear power generation facilities for cooling, make-up, or domestic water uses (see Glossary). A total of eight thermoelectric power generation facilities were in operation within the ACF River Basin during 2005, that included six in Georgia, and one each in Alabama and Florida. A total of 12 hydroelectric facilities also were located within the basin.

In 2005, slightly more than $788 \mathrm{Mgal} / \mathrm{d}$ of water was withdrawn for thermoelectric power generation purposes in the ACF River Basin (table 2). Nearly all of the water used in this category was from surface-water sources (99.94 percent). Cobb County, Ga. (363 Mgal/d) accounted for the largest total water withdrawals for thermoelectric power generation in 2005, followed by Dougherty County, Ga. (120 Mgal/d), Houston County, Ala. (106 Mgal/d), and Jackson County, Fla. (103 Mgal/d; table 5).

Overall, 88 percent $(691 \mathrm{Mgal} / \mathrm{d})$ of the total water withdrawals for thermoelectric power generation in 2005 was used for once-through cooling purposes in the basin. Most of the water withdrawn for this purpose is returned to its source immediately after use. The remaining water ( $97 \mathrm{Mgal} / \mathrm{d})$ is used for boiler make-up, potable uses at the facilities, or to augment cooling ponds or towers. The gross power generated by these eight thermoelectric facilities in 2005 totaled 39,072 gigawatthours (gWh). An additional 37,591 Mgal/d of water was used to generate power at the 12 hydroelectric plants in 2005.

\section{Monthly (Seasonal) Water Withdrawals, 2005}

The amount of water withdrawn annually and monthly (seasonal) fluctuates for all categories because of variations in temperature, precipitation, crop production, tourism, and economics (Marella, 2009). For this report, only monthly withdrawal data for public supply were available and summarized. The variation in monthly water use for public supply is driven primarily by climate, mostly temperature and precipitation (rainfall). Monthly water withdrawals for public supply are typically higher during the spring and summer months, and lower during the fall and winter months. Generally, water demand increases during dry months and decreases during wet months as landscape irrigation needs fluctuate based on temperature and rainfall. Landscape watering (often referred to as lawn watering) is typically the largest outdoor use of public-supply water (Marella, 2009).

Public-supply withdrawals in the ACF River Basin in 2005 varied by about $200 \mathrm{Mgal} / \mathrm{d}$. Withdrawals were lowest in January, February, and March (slightly more than $500 \mathrm{Mgal} / \mathrm{d}$ ), and highest in September (slightly more than $700 \mathrm{Mgal} / \mathrm{d}$ ) and in October (fig. 10). Because rainfall throughout the basin was at or above average in 2005 , monthly water withdrawals for public supply fluctuated by less than $200 \mathrm{Mgal} / \mathrm{d}$ during the year. Monthly water withdrawals for public supply typically fluctuate in response to the amount of precipitation received; specifically, monthly withdrawal totals fluctuate substantially less during average rainfall years than during drier years (Verdi and others, 2006; Fanning, 2009). Because more than 68 percent of the publicsupply water withdrawals in the basin occurred in the eight metropolitan counties of Atlanta, these withdrawals were separated from those in the rest of the basin. Subsequent analysis of public-supply monthly values in this report were subdivided into three areas:

1. Metropolitan Atlanta, Ga., area (Clayton, Cobb, DeKalb, Douglas, Fayette, Fulton, Gwinnett, and Henry Counties);

2. Remaining areas of Georgia within the ACF River Basin (all or part of the remaining 54 counties in Georgia); and

3. All of Alabama and Florida within the ACF River Basin.

Monthly public-supply withdrawals in 2005 were more variable in the Atlanta area than in the other two areas of the basin (fig. 11), as outdoor water use tends to be high in metropolitan areas because of residential and commercial landscape irrigation. Actual rainfall in metropolitan Atlanta for September 2005 was slightly more than 1 inch (in.) - well below the 35-year (1970-2005) September average of 4 in. (U.S. Department of 


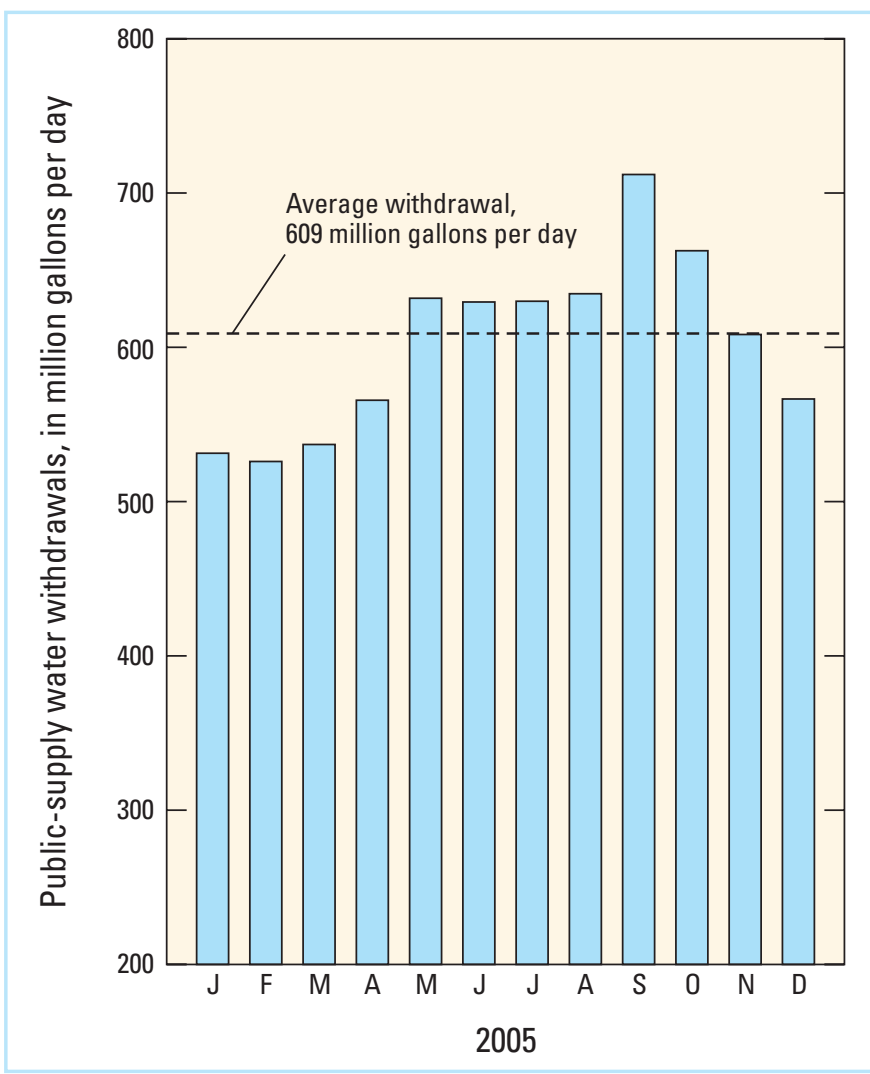

Figure 10. Public-supply average and monthly water withdrawals in the Apalachicola-Chattahoochee-Flint River Basin, 2005.

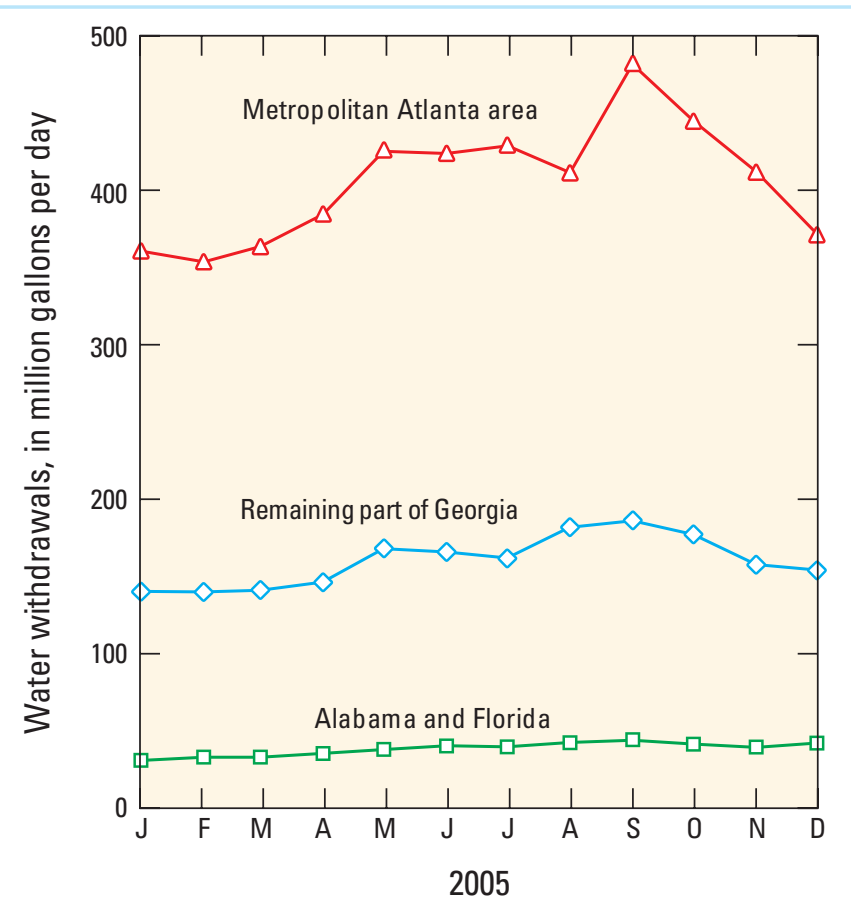

Figure 11. Public-supply monthly water withdrawals by region in the Apalachicola-Chattahoochee-Flint River Basin, 2005.
Commerce, 2008). The metropolitan Atlanta area received near or above average rainfall during the spring and summer months of 2005. Public-supply withdrawals during this period, therefore, showed minimal variation.

\section{Domestic Wastewater Discharge, 2005}

Wastewater discharge includes water released from wastewater treatment facilities, septic tanks, or in some areas, stormwater runoff (Marella, 2004). Discharge for domestic (municipal and privately owned) facilities and some industrial facilities usually are usually regulated and metered, whereas septic tank releases and stormwater runoff usually are not metered. Treated wastewater discharges values in this report are only for domestic wastewater facilities that discharged $0.01 \mathrm{Mgal} / \mathrm{d}$ or more during 2005 . For this report, discharge data for industrial wastewater were not compiled, and water releases from septic tanks were not estimated.

Domestic wastewater facilities, commonly called wastewater treatment facilities or water pollution control facilities, are those systems that receive and dispose of wastewater derived principally from occupants of residential dwellings, business or commercial establishments, institutions, and industrial facilities (see glossary). Data were obtained for 95 domestic wastewater facilities within the ACF River Basin that discharged 0.01 Mgal/d or more during 2005; their combined reported flow was $413 \mathrm{Mgal} / \mathrm{d}$. Nearly all (slightly more than 99 percent) of the domestic wastewater was discharged to surface-water sources, and the remainder was discharged through land-application systems (drainfields, percolation ponds, sprayfields) and reuse systems. Fulton County, Ga., accounted for nearly 47 percent of the wastewater discharge in the basin (192 Mgal/d), followed by Cobb County, Ga., at nearly 14 percent (56 Mgal/d; table 6).

Two types of wastewater are generally transported to treatment facilities: (1) base-line flow composed of discharge from residential dwellings, business or commercial establishments, and industrial facilities; and (2) infiltration into wastewater collection systems (U.S. Environmental Protection Agency, 1996). Flows from residential, commercial, and industrial users most often remain fairly consistent throughout the year with little monthly variation. Infiltration usually occurs directly from stormwater runoff or indirectly from a rise in shallow groundwater levels that seep into return or collection piping. Infiltration from stormwater runoff varies daily and monthly and depends upon rainfall events or totals. Therefore, monthly domestic wastewater discharges are usually largest during the rainy season or periods of heavy rainfall. Domestic wastewater discharge, which averaged about $413 \mathrm{Mgal} / \mathrm{d}$ in 2005, was lowest in September, October, and November, and highest in March, April, and July (fig. 12). Monthly discharge variation was minimal within each subregion during 2005 (fig. 13). 
Table 6. Domestic wastewater discharge by source in the Apalachicola-Chattahoochee-Flint River Basin by county, 2005. [Compiled by the U.S. Geological Survey; all values in million gallons per day; - , discharge was less than 0.01 or no discharge was reported]

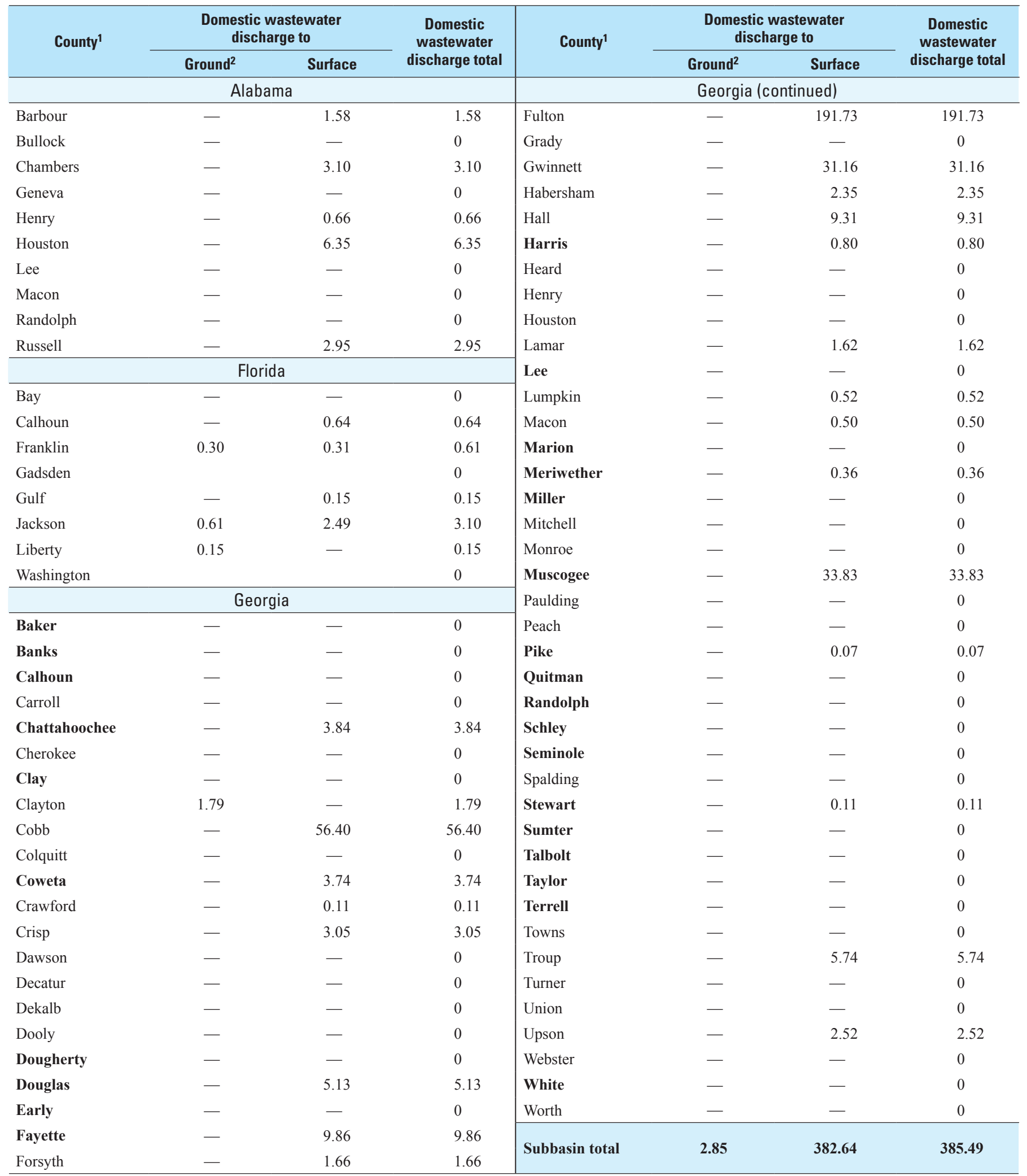

${ }^{1}$ County names in bold indicate that the county is entirely within the basin. All other counties are only partially within the basin. Values shown are for the Apalachicola-Chattahoochee-Flint River Basin part only.

${ }^{2}$ Groundwater discharge includes drainfields, perculation ponds, sprayfields, and reuse systems. 


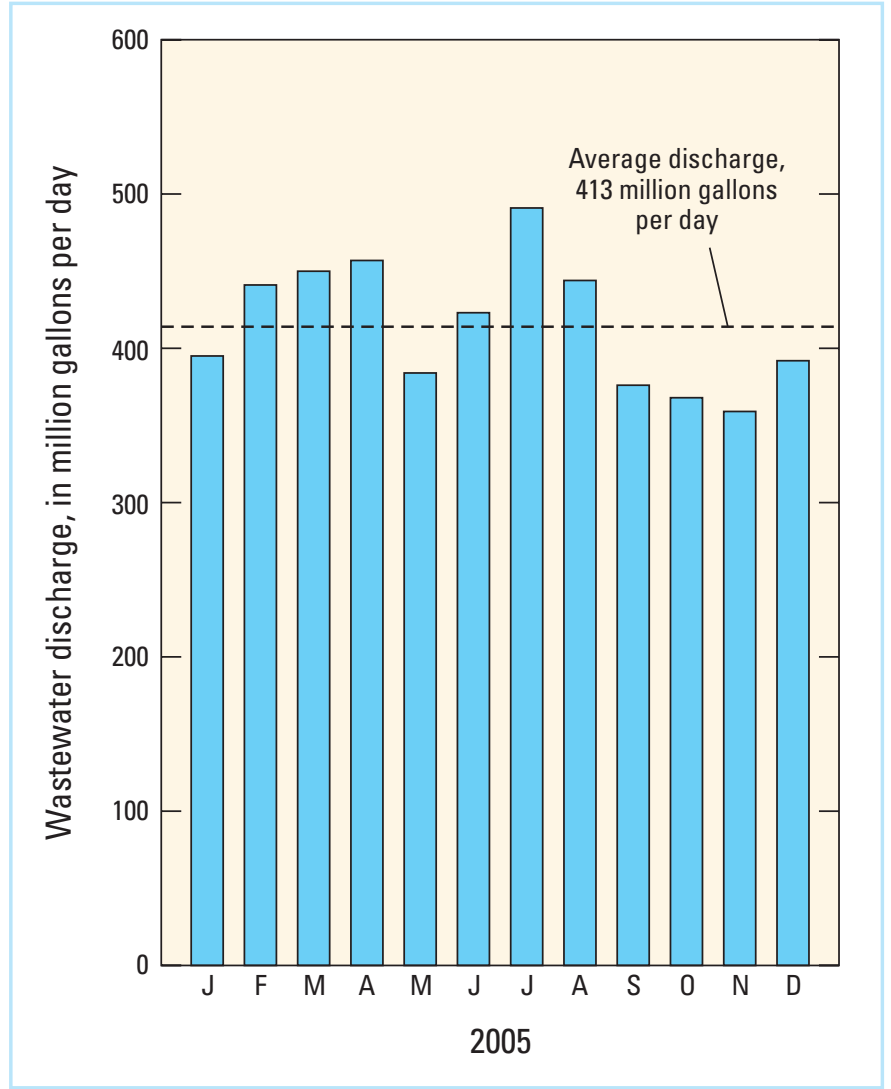

Figure 12. Domestic wastewater average and monthly discharges in the Apalachicola-Chattahoochee-Flint River Basin, 2005.

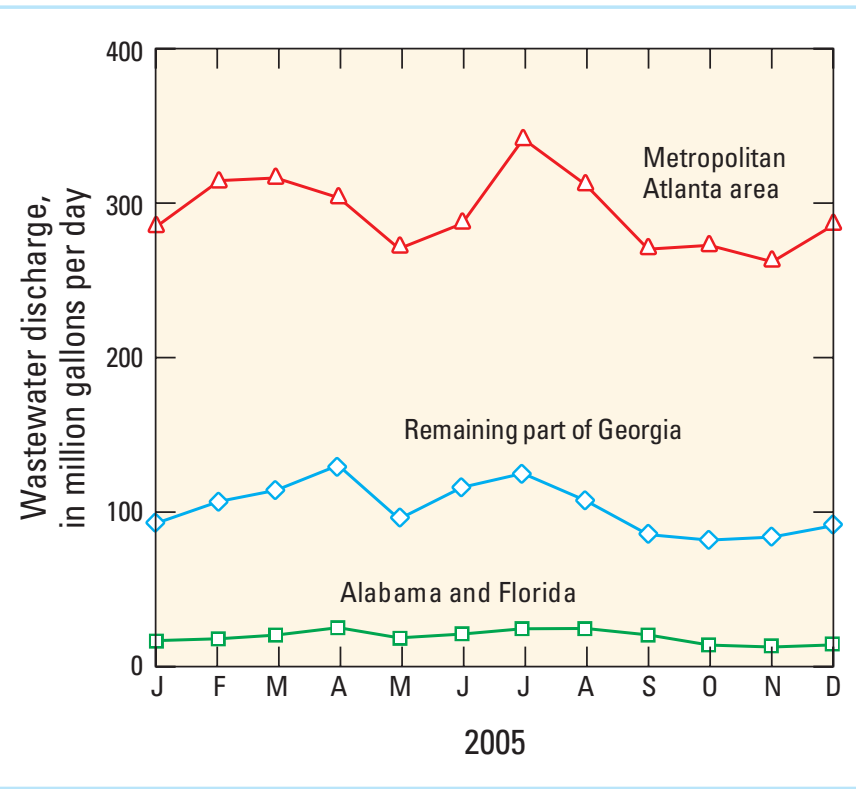

Figure 13. Domestic wastewater discharge in the Apalachicola-Chattahoochee-Flint River Basin by region, 2005.

\section{Estimated Public-Supply Water Consumption, 2000 and 2005}

Public-supply water consumption for 2000 and 2005 was estimated from the cumulative difference between the monthly amount of public-supply water withdrawn and the monthly amount of domestic wastewater returned. This difference was considered consumed, as it was deemed lost due to evaporation, runoff, or percolation. In addition, water withdrawn for public supply within the basin that is used and discharged outside of the basin is also considered consumed.

Estimated consumption of water withdrawn for public supply in the ACF River Basin varied between 2000 and 2005. For 2000, public-supply consumption was estimated to be 49 percent, meaning that 51 percent of the water withdrawn for public supply in the basin was returned to the hydrologic system for immediate use through wastewater treatment systems. Using an average monthly discharge of $342 \mathrm{Mgal} / \mathrm{d}$ for 2000, most of the water consumption that occurred between May and August (fig. 14A) was between 53 to 57 percent of the water that was consumed. The average monthly wastewater discharge was used to help offset the large infiltration of surface-water runoff into wastewater collection systems during heavy rainfall events; however, for 2000, the reported monthly discharge values did not vary much from the average (fig. 14A). The year 2000 was considered a dry year, because average rainfall for the basin was 42 in. (fig. 3), 11 in. less than the 35-year average.

Public-supply consumption for 2005 was estimated to be 38 percent, meaning that 62 percent of the water withdrawn for public supply in the basin was returned to the hydrologic system for immediate use through wastewater treatment systems (fig. 14B). Using an average monthly discharge of $380 \mathrm{Mgal} / \mathrm{d}$ for 2005, the highest water consumption that occurred in September (fig. 14B) was 53 percent of the water that was consumed. The average monthly wastewater discharge for 2005 was calculated using only the 6 months of lowest returns (January, May, September, October, November, and December) as the minimal base return flow. Had the remaining 6 months been used, the annual average of $413 \mathrm{Mgal} / \mathrm{d}$ would have been used. The year 2005 was considered a wet year, because average rainfall for the basin was 60 in. (fig. 3), 7 in. more than the 35 -year average.

\section{Trends in Water Withdrawals, 1970-2005}

Statewide water withdrawal and water-use estimates have been compiled for Alabama, Florida, and Georgia every 5 years since 1980 . For this report, the values collected and published by the State or USGS for these 5-year intervals are used to formulate trends. However, because of changes in data-collection techniques and information sources through 

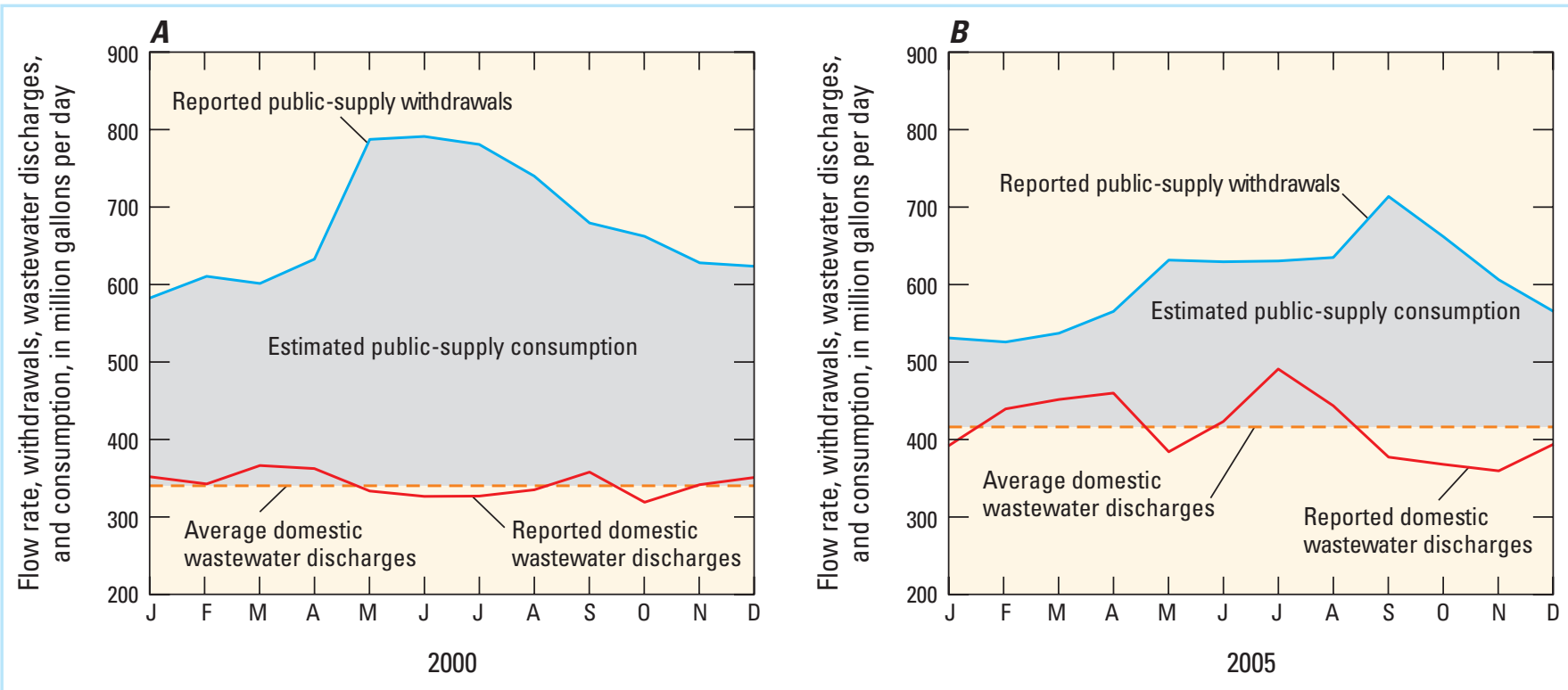

Figure 14. Public-supply monthly water withdrawals, domestic wastewater returns, and consumption in the ApalachicolaChattahoochee-Flint River Basin for $A, 2000$, and B, 2005.

the years, historical water-use trends are sometimes difficult to assess (Marella, 2009). In addition, when water-use data are only compiled at 5-year intervals, unique circumstances occurring within a year can influence the annual values and make yearly data comparisons difficult. For example, water withdrawals for 2000 increased substantially from previous years. However, because of extreme dry conditions across the southeastern United States and throughout the ACF River Basin during 2000, the majority of the increase in water use from the previous years is more likely the result of belowaverage basinwide rainfall (U.S. Department of Commerce, 2008) (fig. 3) with a smaller percentage of the increase due to changes in human activities, such as population growth or acreage production. The effect of rainfall on water demand is evident for both agricultural irrigation and public supply, because additional water is needed to offset low rainfall amounts that are typical during spring and early summer when irrigation of crops and landscape (primarily lawn watering) increases (Verdi and others, 2006).

\section{Total Water-Withdrawal Trends}

Between 1970 and 2005, total water withdrawals (ground and surface) in the ACF River Basin increased by more than $515 \mathrm{Mgal} / \mathrm{d}$ (35 percent; fig. 15 and table 7), as the basin population increased by 1.7 million ( 83 percent). During this 35 -year period, groundwater withdrawals increased nearly 350 percent (309 Mgal $/ \mathrm{d}$ ), whereas surfacewater withdrawals increased by 15 percent $(206 \mathrm{Mgal} / \mathrm{d})$.

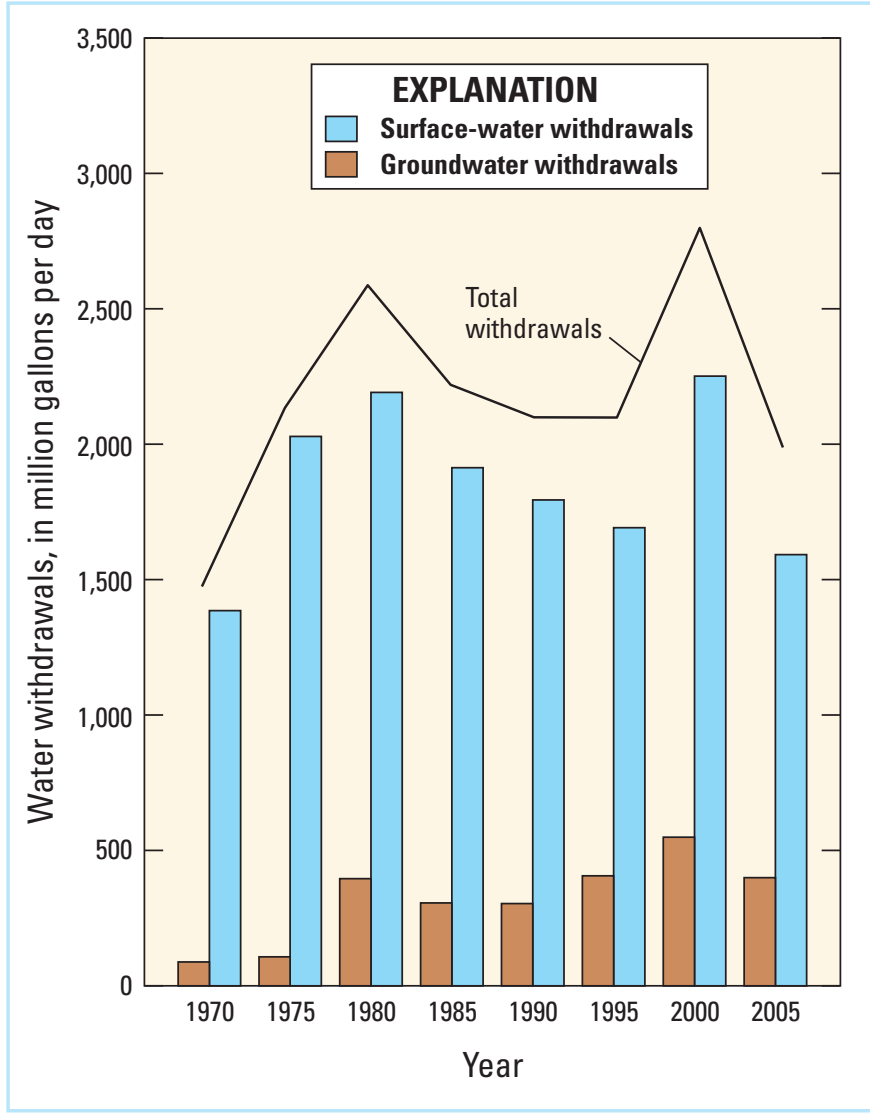

Figure 15. Total water withdrawals by water source in the Apalachicola-Chattahoochee-Flint River Basin, 1970-2005. 


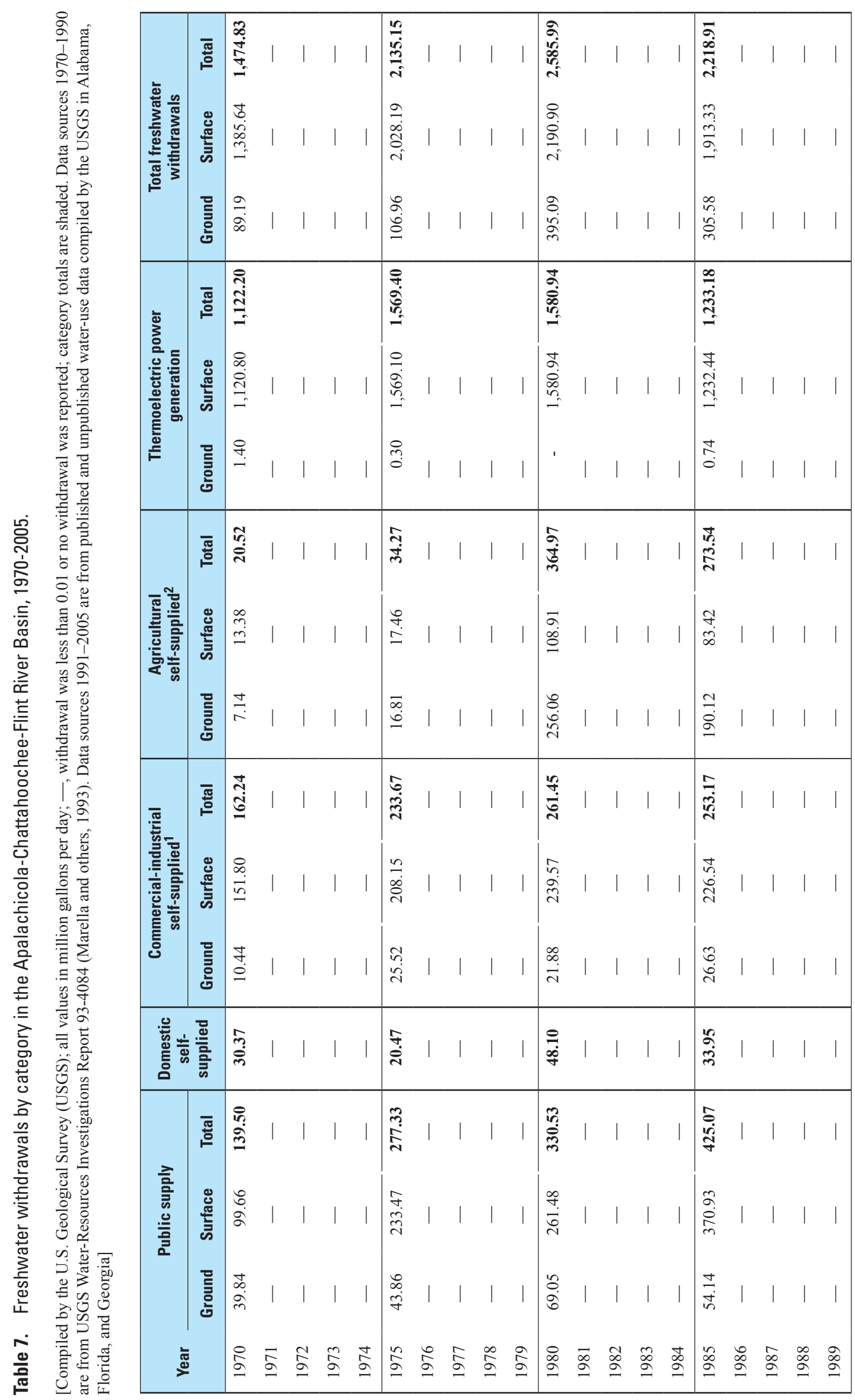




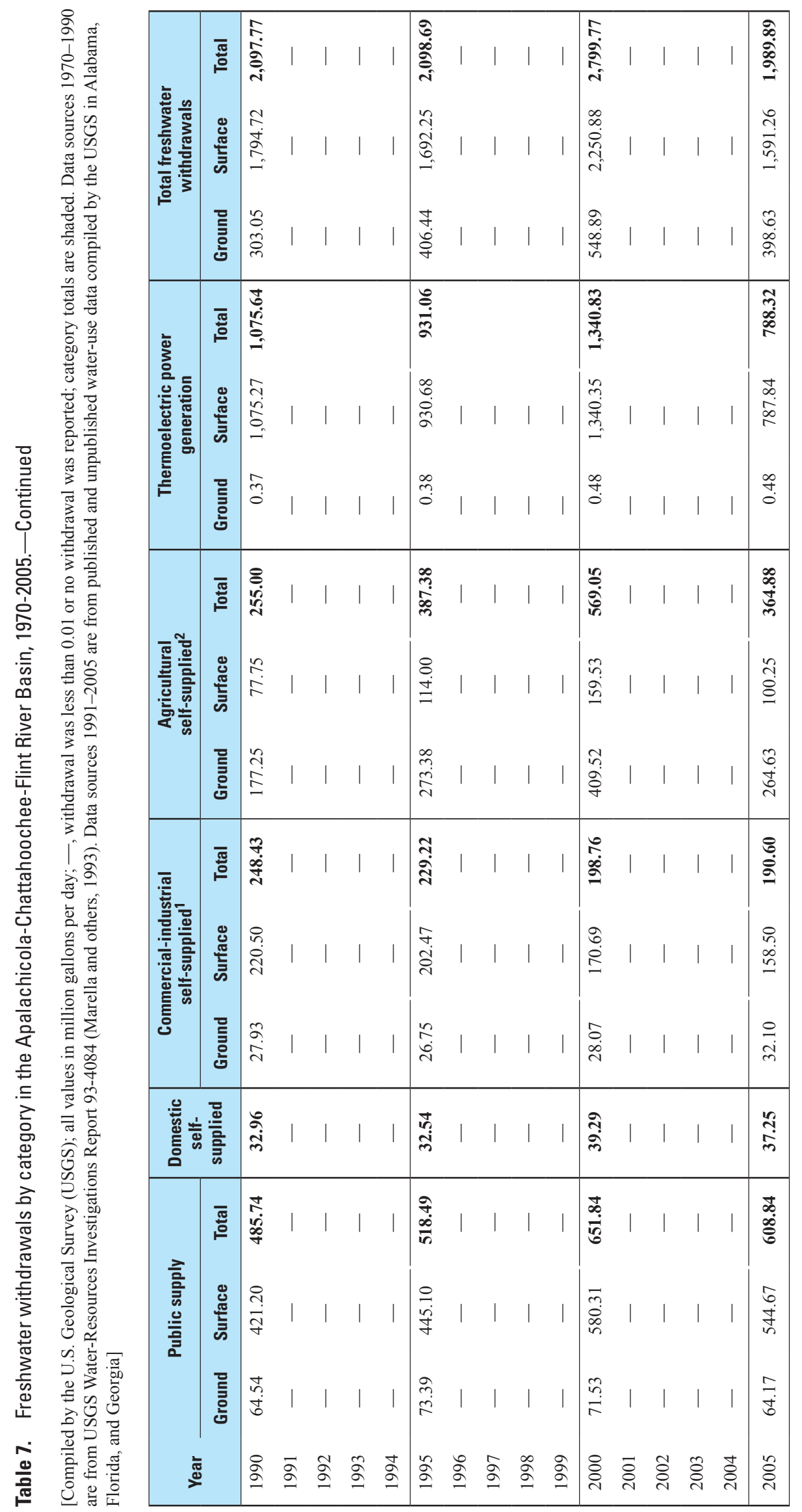

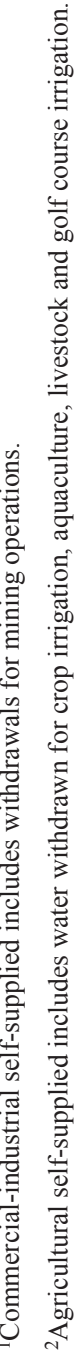


Both groundwater and surface-water withdrawals peaked in 2000 and decreased between 2000 and 2005 (fig. 15). Total withdrawals were highest in 1980 and 2000 (fig. 15 and table 7). Since 1980, surface-water withdrawals have declined, with the exception of 2000.

Water use by category changed considerably between 1970 and 2005. In particular, thermoelectric power generation decreased from 76 percent of the total withdrawals in the ACF River Basin in 1970 to 40 percent in 2005 (fig. 16). This decline is a result of decreased water demand for thermoelectric power generation as powerplants have closed or become more water efficient over time (Fanning and Trent, 2009). In contrast, water withdrawals for public supply and agricultural irrigation have increased substantially (fig. 16). Public supply increased from about 10 percent of the total withdrawals in 1970 to about 30 percent in 2005, and agricultural irrigation from about 1 percent of the total withdrawals in 1970 to about 18 percent in 2005 (fig. 16). These increases are the result of concurrent increases in (1) a basinwide population dependent upon public-supply water, and (2) agricultural crop acreage dependent upon water for irrigation. Most of the increases in public-supply withdrawals are from surface-water sources in the northern part of the basin, whereas most of the increases in agricultural irrigation withdrawals are from groundwater sources in the southern and central parts of the basin.

\section{Water Withdrawal-Trends by Category}

Total public-supplied water withdrawals in the ACF River Basin increased by nearly $470 \mathrm{Mgal} / \mathrm{d}$ (336 percent) between 1970 and 2005, but decreased by $43 \mathrm{Mgal} / \mathrm{d}$ (7 percent) between 2000 and 2005 (fig. 17 and table 7). Increases in public-supply withdrawals are a result of population growth over a 35 -year period in the basin, and the increased dependence on water from the Chattahoochee River and its tributaries by a large and growing population living outside the basin. The total population served by public-supply within the basin increased from 1.633 million in 1970 to 3.237 million in 2005, an increase of 1.604 million or 98 percent (fig. 2). In addition, the estimated population served living outside the basin using water obtained within the basin totaled 1.080 million in 2005, compared to 0.650 million in 2000 (no data were available for previous years). Also, water demands from commercial and industrial facilities that obtain their water from public-supply water systems increased in the basin between 1970 and 2005.

Public-supply per capita water use for the basin was calculated to be $141 \mathrm{gal} / \mathrm{d}$ in 2005 , compared to $85 \mathrm{gal} / \mathrm{d}$ in 1970. The basinwide per capita use has been declining since 1990, which was estimated at $212 \mathrm{gal} / \mathrm{d}$, compared with $203 \mathrm{gal} / \mathrm{d}$ in 1995, and $182 \mathrm{gal} / \mathrm{d}$ in 2000. Public-supply per capita water use computed by this method includes water provided for all uses of public-supply water (including domestic, commercial, industrial, and other uses) and losses

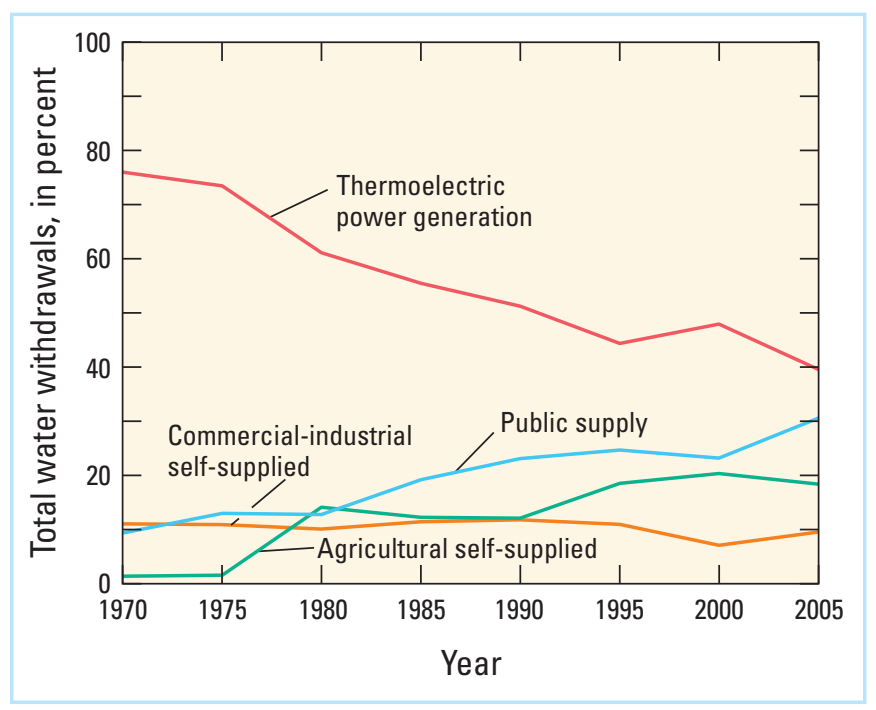

Figure 16. Percentage of total water withdrawals by category in the Apalachicola-Chattahoochee-Flint River Basin, 1970-2005.

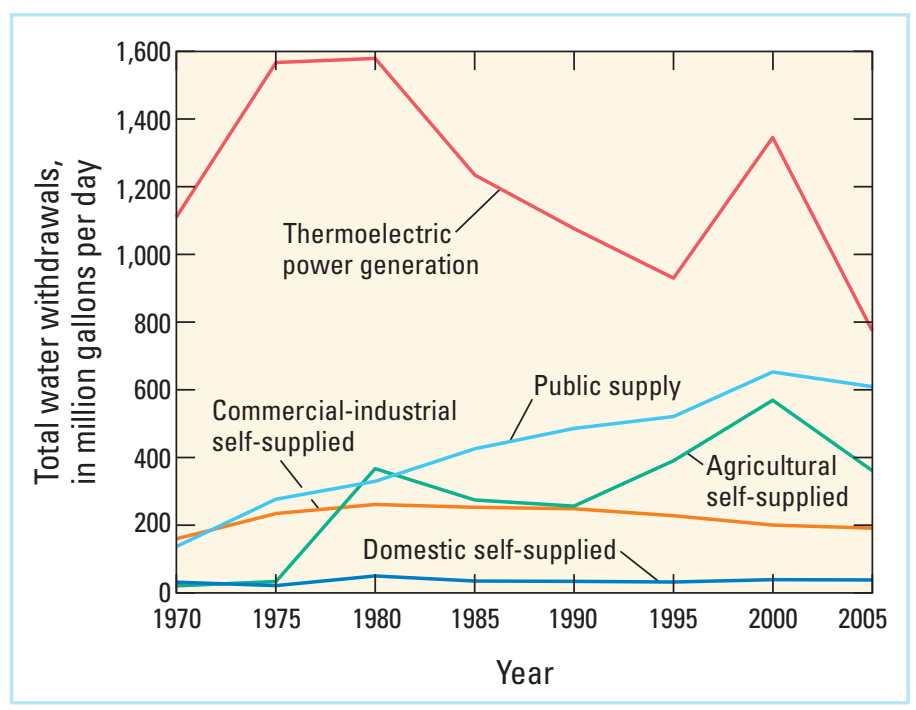

Figure 17. Total water withdrawals by category in the Apalachicola-Chattahoochee-Flint River Basin, 1970-2005.

(Marella, 2009). Declines in per capita use are a direct result in water conservation efforts, changes in housing units or lot sizes (from single family to multifamily units or zero-lotline properties), changes in household plumbing and appliance technology (as they have become more water efficient over time), and changes in the methodology used to estimate the population served. 
Domestic self-supplied withdrawals have generally ranged about $30 \mathrm{Mgal} / \mathrm{d}$ between 1970 and 2005 (fig. 17 and table 7). During this period, the population in the basin that makes up the domestic self-supplied category has increased by less than 0.100 million people-from 0.408 million in 1970 to 0.494 million in 2005 . The majority of people and water withdrawals in the domestic self-supplied category continue to be in the largely rural southwestern Georgia area. All withdrawals for domestic self-supplied use are most likely (and assumed to be) from groundwater sources (table 7).

Although total water withdrawals for commercialindustrial self-supplied use in the ACF River Basin increased about $28 \mathrm{Mgal} / \mathrm{d}$ (17 percent) between 1970 and 2005, withdrawals decreased $8 \mathrm{Mgal} / \mathrm{d}$ (4 percent) between 2000 and 2005 (fig. 17 and table 7). Commercial-industrial self-supplied withdrawals have remained nearly the same or have decreased somewhat since the 1980s. More recently, a decline in manufacturing across the southeastern United States, coupled with the closure of several large manufacturing facilities within the basin, has caused withdrawals to decline somewhat over the past 10 to 15 years. In addition, some self-supplied commercial and industrial users have switched to using public supply as their water source during this period, while other self-supplied facilities have become more efficient or have begun to recirculate water, primarily to lower their discharge amount. A large number of commercial and industrial users within the basin obtain their water from a public-supply water system.

Total withdrawals for agricultural self-supplied in the basin increased by about $344 \mathrm{Mgal} / \mathrm{d}$ (nearly 1,700 percent) between 1970 and 2005, but decreased by $204 \mathrm{Mgal} / \mathrm{d}$ (36 percent) between 2000 and 2005 (fig. 17 and table 7). This long-term increase in agricultural self-supplied withdrawals is a result of the development and installation of irrigation systems in southern Georgia, coupled with an abundance of high quality water for irrigation in this area (Pierce and others, 1984). The more recent trend is a result of differences in annual or seasonal rainfall in southern Georgia over the past 10 years, in addition to changes in the methodology used to estimate irrigation demands and changes in irrigation practices. Total agricultural self-supplied withdrawals were 55 percent higher in 2000 than in 2005; drier years, such as 2000 , typically require more supplemental irrigation to offset the lack of rainfall (fig. 17 and fig. 3). Specifically, this recent decline is due to many factors, including a 42-percent increase in basinwide average annual rainfall and a 2-percent decrease in irrigated acreage between 2000 and 2005. In addition to rainfall and irrigation differences between 2000 and 2005, changes in agricultural self-supplied withdrawals may also be the result of better management practices by farmers, new irrigation conservation measures, and imposed water restrictions (Tyson and Harrison, 1993; and Kerry Harrison and James Hook, University of Georgia, written commun., 2009).

Total water withdrawals for thermoelectric power generation in the ACF River Basin decreased by $334 \mathrm{Mgal} / \mathrm{d}$ (30 percent) between 1970 and 2005 and $553 \mathrm{Mgal} / \mathrm{d}$
(41 percent) between 2000 and 2005 (fig. 17 and table 7). The majority of the water withdrawn for thermoelectric power generation in the basin was used for oncethrough cooling. Overall, this long-term decrease in water withdrawals in thermoelectric power generation is a result of an increase in water efficiency in the power industry across the South coupled with the opening of several large facilities that help offset the production at some of the smaller powerplants. The gross power generated at the eight thermoelectric facilities within the basin totaled 39,072 $\mathrm{gWh}$ for 2005, compared with 33,460 $\mathrm{gWh}$ for 1990 (Marella and others, 1993).

\section{Monthly (Seasonal) Water-Withdrawal Trends}

Monthly (seasonal) variation in water withdrawals is typical in Alabama, Florida, and Georgia. Within the ACF River Basin, agricultural self-supplied withdrawals would be expected to have the largest fluctuation of all the monthly water withdrawals, because crops are grown during the spring and early summer months when rainfall is typically minimal or sporadic at best. However, estimates of monthly agricultural self-supplied withdrawals for 2005 were not available and are not included in this report. Because a large percentage of public-supply water used within the basin is for lawn irrigation, the variation in monthly withdrawals during certain times of the year can be relatively large.

In a manner similar to the relation between annual rainfall totals and annual withdrawal patterns, monthly rainfall totals provide insight about seasonal withdrawal patterns. For 1995, 2000 , and 2005, annual basinwide rainfall totaled 52, 42, and 60 in., respectively, and public-supply water withdrawals averaged 520, 652, and $609 \mathrm{Mgal} / \mathrm{d}$, respectively. During these same years, however, public-supply withdrawals varied greatly between months (fig. 18). During 2000, for example, monthly public-supply withdrawals increased sharply during the spring to a maximum of $790 \mathrm{Mgal} / \mathrm{d}$ in May, and gradually declined thereafter. Withdrawals during 2005 increased through May and remained constant through the summer months before peaking at nearly $712 \mathrm{Mgal} / \mathrm{d}$ in September. Public-supply withdrawals during 1995 rose in a stepwise manner throughout spring and early summer, peaked at nearly $645 \mathrm{Mgal} / \mathrm{d}$ in July, and declined steadily thereafter (fig 18). The variation in monthly public-supply water withdrawals for these 3 years are the result of demand caused by outdoor water uses, primarily lawn watering. Little or inconsistent rainfall coupled with high evaporation rates during hot months increase demands for public-supply water across the basin.

Monthly public-supply withdrawals were compared to the actual average monthly rainfall for the eight metropolitan Atlanta counties from 1990 through 2007 (fig. 19). During this 18-year period, several trends are evident: (1) peak public-supply withdrawals occur during the late spring or summer months; (2) during many of the peak withdrawal periods, rainfall amounts are correspondently low; (3) periods 


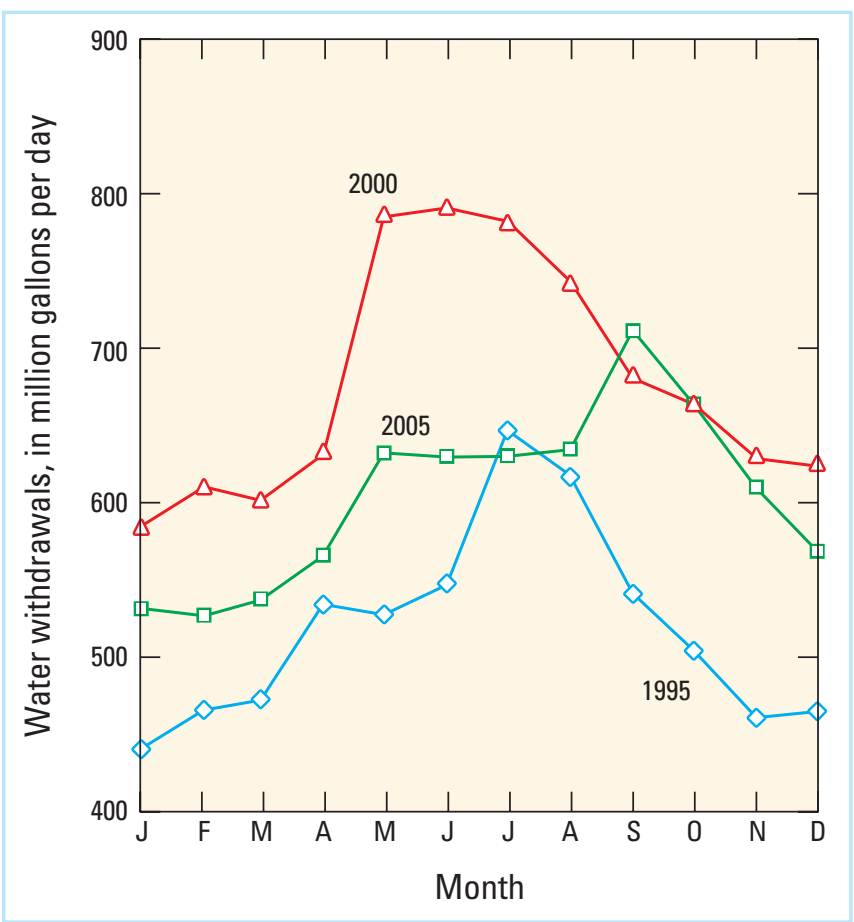

Figure 18. Public-supply monthly water withdrawals in the Apalachicola-Chattahoochee-Flint River Basin, 1995, 2000, and 2005.

of low public-supply withdrawals are either winter months or months with high rainfall totals; and (4) public-supply average withdrawals show an increasing trend between 1990 and 2007.

\section{Wastewater Discharge Trends, 1990-2005}

Domestic (municipal) wastewater discharge data for the ACF River Basin were compiled sporadically between 1970 and 2005, with complete datasets obtained for 1990, 2000, and 2005. Domestic wastewater discharges increased from $223 \mathrm{Mgal} / \mathrm{d}$ in 1990 (Marella and others, 1993) to $343 \mathrm{Mgal} / \mathrm{d}$ in 2000 to $413 \mathrm{Mgal} / \mathrm{d}$ in 2005 (fig. 20). The change in total domestic wastewater discharge is primarily a result of an increase in population in the basin's urban areas, which are generally served by wastewater facilities, and the expansion of service areas outside the basin.

Seasonal trend data for domestic wastewater returns in the ACF River Basin are only available for 2000 and 2005. Monthly discharge data for 2000 show far less variation in monthly discharge than 2005 (fig. 21). This difference is primarily due to minimal surface-water runoff into wastewater collection systems because of below average rainfall for 2000 . In contrast, monthly discharge data for 2005 show variation in monthly discharge, primarily due to substantial surface-water runoff into wastewater collection systems because of above average rainfall during 2005.

\section{Summary}

The Apalachicola-Chattahoochee-Flint (ACF) River Basin drains parts of Alabama, Florida, and Georgia from its headwaters in northern Georgia to the Gulf of Mexico. The river basin was home to about 3.7 million people in 2005 , with 63 percent of the basin population residing within the metropolitan Atlanta area. Slightly more than 721,000 acres of crops were irrigated within the basin in 2005, with 75 percent of the acreage occurring within southwestern Georgia.

Increasing population growth and agricultural production from the 1970 s to present has substantially increased the demand on the water resources of the ACF River Basin. In addition to water withdrawn for human activities, water is needed for fish and wildlife and to sustain a healthy natural ecosystem. Annual and seasonal fluctuations in rainfall further compound these issues, and create conflicting water demands within the basin. Improved understanding of annual and seasonal trends in the amount of water used for human activities will assist with water management of this important resource.

The total amount of water withdrawn in the ACF River Basin in 2005 was estimated to be $1,990 \mathrm{Mgal} / \mathrm{d}$, and was all considered freshwater. Surface water accounted for $1,591 \mathrm{Mgal} / \mathrm{d}$ (80 percent) and groundwater accounted for $399 \mathrm{Mgal} / \mathrm{d}$ (20 percent) of the total water withdrawn. Because of the location and availability of the water resources in the basin, the majority of water withdrawn in the northern and central parts of the basin is surface water, whereas the primary water source in the southern areas of the basin is groundwater where it is more readily available. The Chattahoochee River was the largest supplier of surface water in the basin, and the Floridan aquifer system was the primary source of groundwater in the basin during 2005.

Thermoelectric power generation accounted for the largest percentage of water withdrawn, composing $788 \mathrm{Mgal} / \mathrm{d}$ (40 percent) of the total for all categories; however, most of the use was nonconsumptive. Water used for public supply accounted for about $609 \mathrm{Mgal} / \mathrm{d}$ (30 percent) of the total water withdrawn, followed by agricultural self-supplied at $365 \mathrm{Mgal} / \mathrm{d}$ (18 percent), commercial-industrial self-supplied at $191 \mathrm{Mgal} / \mathrm{d}$ (10 percent), and domestic self-supplied at $37 \mathrm{Mgal} / \mathrm{d}$ (2 percent).

Surface water accounted for the majority of public supply withdrawals, $545 \mathrm{Mgal} / \mathrm{d}$ (89 percent), and groundwater supplied the remaining $64 \mathrm{Mgal} / \mathrm{d}$ (11 percent). Publicsupply withdrawals in the basin varied by about $200 \mathrm{Mgal} / \mathrm{d}$ in 2005. Withdrawals in 2005 were lowest in January, February, and March (slightly more than $500 \mathrm{Mgal} / \mathrm{d}$ ), and highest in September (slightly more than $700 \mathrm{Mgal} / \mathrm{d}$ ) and in October. In 2005, water withdrawn for public-supply use provided drinking water to nearly 4.317 million people; however, not all of these people resided within the ACF River Basin. An estimated 1.080 million people were located outside of the basin but obtained their public-supply water from a withdrawal source within the basin, mostly in the 

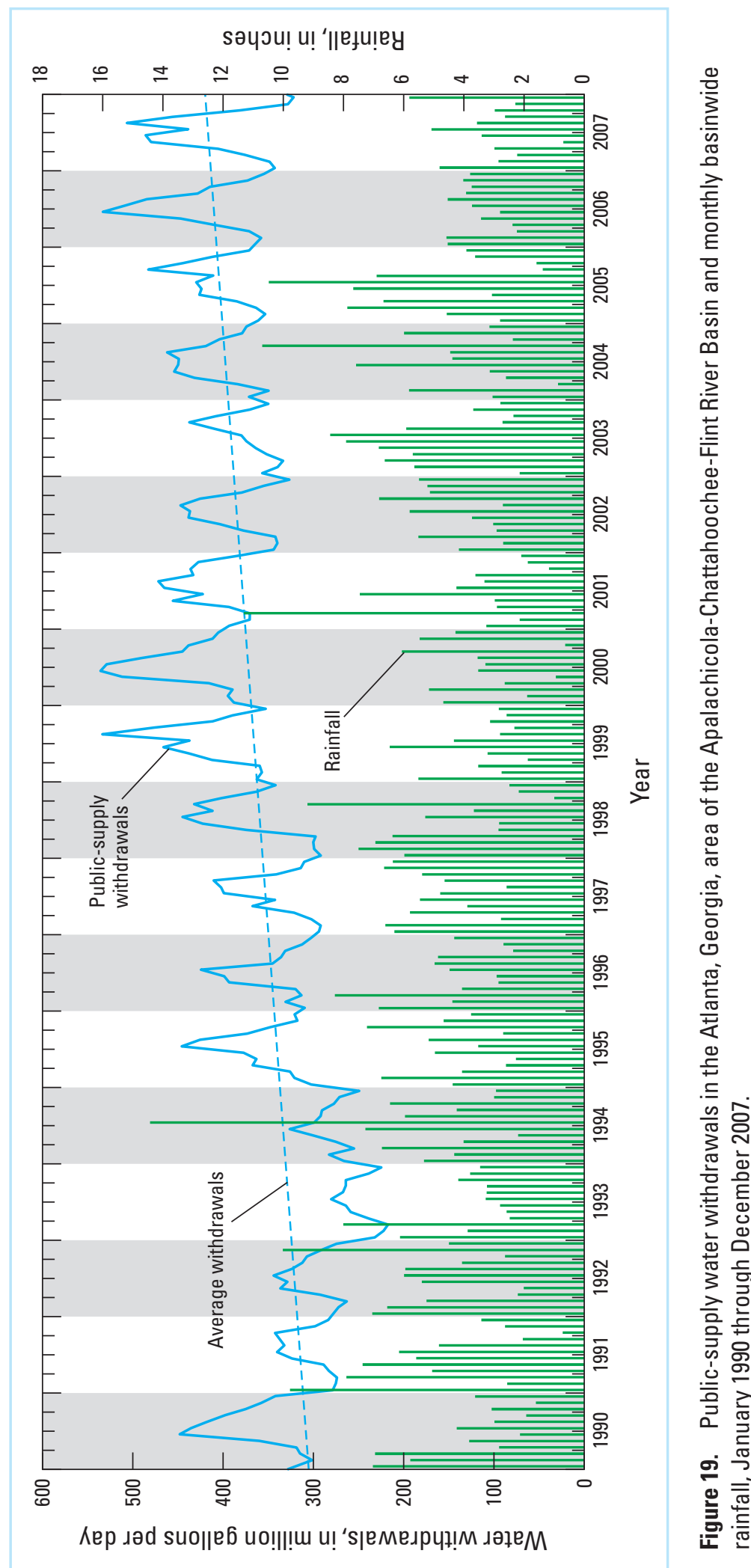


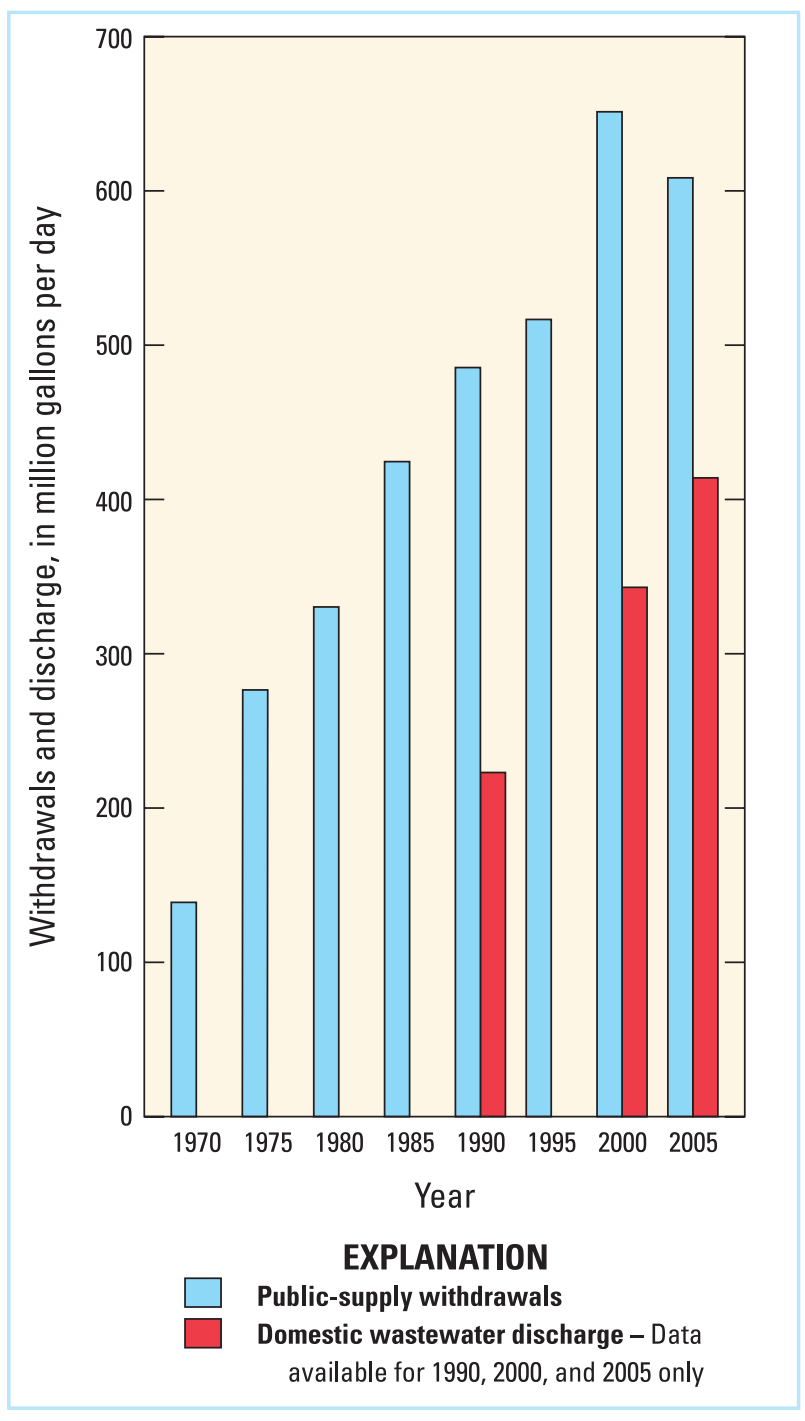

Figure 20. Public-supply water withdrawals and domestic wastewater returns in the ApalachicolaChattahoochee-Flint River Basin, 1970-2005.

metropolitan Atlanta area. Overall, 3.237 million people within the basin obtained water from a public-supply water system in 2005 . About 87 percent (3.775 million) of the total population served obtained public-supply drinking water from surface-water sources in 2005, whereas the remaining 13 percent ( 0.542 million) obtained drinking water from groundwater sources. Slightly less than a half million people ( 0.496 million or 13 percent of the basin population) not served by an inventoried public supplier were considered selfsupplied in 2005. Domestic self-supplied water withdrawals totaled $37 \mathrm{Mgal} / \mathrm{d}$ in the basin and are assumed to be obtained from groundwater sources only. Surface water accounted for the majority of commercial-industrial self-supplied withdrawals, $159 \mathrm{Mgal} / \mathrm{d}$ (83 percent) and groundwater supplied the remaining $32 \mathrm{Mgal} / \mathrm{d}$ (17 percent). The majority of water

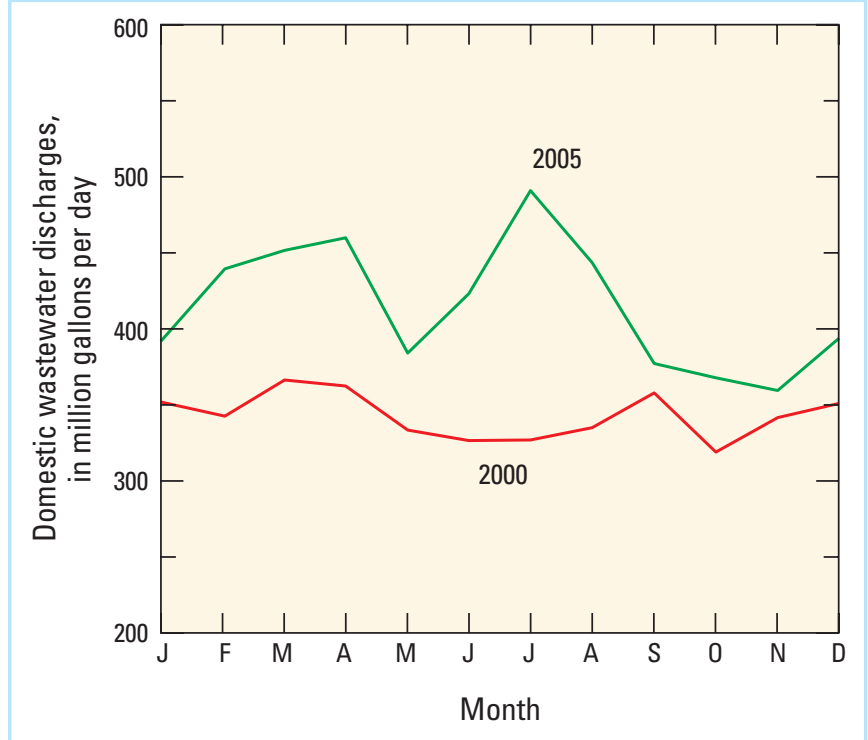

Figure 21. Monthly domestic wastewater returns in the Apalachicola-Chattahoochee-Flint River Basin, 2000, and 2005.

withdrawals in this category were for industrial purposes (88 percent), whereas commercial and mining withdrawals accounted for 6 percent each. Groundwater supplied about $265 \mathrm{Mgal} / \mathrm{d}$ (73 percent) of the total water withdrawn for agricultural self-supplied in 2005 , whereas the remaining $100 \mathrm{Mgal} / \mathrm{d}$ (27 percent) was from surface-water sources. Overall, water used for crop irrigation accounted for about 98 percent of the water withdrawn in this category with the remaining 2 percent withdrawn for golf course irrigation and nonirrigation uses (primarily livestock watering and fish farming). Nearly all water used for thermoelectric power generation purposes in 2005 (788 Mgal/d) was from surface-water sources (99.94 percent). Overall, $691 \mathrm{Mgal} / \mathrm{d}$ (88 percent) of the total water withdrawn for thermoelectric power generation was used for once-through cooling purposes in the basin.

In 2005, data were obtained for 95 domestic wastewater facilities within the ACF River Basin, and their combined reported flow was $413 \mathrm{Mgal} / \mathrm{d}$. Slightly more than 99 percent of the domestic wastewater was discharged to surface-water sources, and the remainder was discharged through landapplication systems (drainfields, percolation ponds, and sprayfields) and reuse systems.

Public-supply water consumption for 2000 and 2005 was estimated from the cumulative difference between the amount of public-supply water withdrawn and the amount of domestic wastewater returned. For 2000, public-supply consumption was estimated to be 49 percent, meaning that 51 percent of the water withdrawn for public supply in the basin was returned to the hydrologic system for immediate use through wastewater treatment systems. For 2005, public-supply consumption was estimated to be 38 percent, meaning that 
62 percent of the water withdrawn for public supply in the basin was returned to the hydrologic system for immediate use through wastewater treatment systems. The year 2000 was considered a dry year, because average rainfall for the basin was $42 \mathrm{in.} \mathrm{(11} \mathrm{in.} \mathrm{below} \mathrm{the} \mathrm{35-year} \mathrm{average).} \mathrm{The} \mathrm{year} 2005$ was considered a wet year, because average rainfall for the basin was 60 in. (7 in. above the 35-year average).

As the population of the ACF River Basin increased by 1.7 million ( 83 percent) in the 35 years between 1970 and 2005 , total withdrawals in the basin increased by more than $515 \mathrm{Mgal} / \mathrm{d}$ (35 percent). Of this increase, surface-water accounted for $206 \mathrm{Mgal} / \mathrm{d}$ (15 percent) and groundwater accounted for $309 \mathrm{Mgal} / \mathrm{d}$ (350 percent). Both groundwater and surface-water withdrawals peaked in 2000, and decreased between 2000 and 2005. Total withdrawals were highest in 1980 and 2000. Since 1980, surface-water withdrawals have declined, with the exception of 2000.

Water use by category changed considerably between 1970 and 2005. In particular, thermoelectric power generation decreased from 76 percent of the total withdrawals in the ACF River Basin in 1970 to 40 percent in 2005. In contrast, water withdrawals for public supply and agricultural irrigation increased substantially. Public supply increased from about 10 percent of the total withdrawals in 1970 to about 30 percent in 2005, and agricultural irrigation increased from about 1 percent of the total withdrawals in 1970 to about 18 percent in 2005. These increases are the result of concurrent increases in (1) a basinwide population dependent upon public-supply water, and (2) agricultural crop acreage dependent upon water for irrigation.

\section{References Cited}

Baker, R.M, and Mooty, W.S., 1987, Use of water in Alabama, 1985: Tuscaloosa, Alabama Geological Survey Information Series 59D, $51 \mathrm{p}$.

Bielby, Camille, 1987, Northwest Florida Water Management District 1985 annual water use survey: Havana, Northwest Florida Water Management District Program Development Series 87-1, 107 p.

Clarke, J.S., and Pierce, R.R., 1985, Georgia ground-water resources, in National Water Summary, 1984-Hydrologic events, selected water quality trends and ground-water resources: U.S. Geological Survey Water-Supply Paper 2275, p. 179-184.

Darst, M.R., and Light, H.M., 2008, Drier forest composition associated with hydrologic change in the Apalachicola River floodplain, Florida: U.S. Geological Survey Scientific Investigations Report 2008-5062, 81 p.
Edmiston, H.L., and Tuck, H.A., 1987, Resource inventory of the Apalachicola River and Bay drainage basin: Apalachicola, Florida Game and Fresh Water Fish Commission, Office of Environmental Services, 303 p.

Fanning, J.L., 2009, Effectiveness of water-management actions during droughts in the Chattahoochee River subbasin, metropolitan Atlanta area, 1995-2008, in Proceedings of the 2009 Georgia Water Resources Conference, April 27-29, 2009: Athens, University of Georgia, 4 p.

Fanning, J.L., and Trent, V.P., 2009, Water use in Georgia by county for 2005, and water-use trends 1980-2005: Atlanta, U.S. Geological Survey Scientific Investigations Report 2009-5002, 186 p.

Georgia Department of Natural Resources, 1984a, Water availability and use, Chattahoochee River subbasin Georgia, 1984: Atlanta, Georgia Environmental Protection Division, 99 p.

Georgia Department of Natural Resources, 1984b, Water availability and use, Flint River subbasin Georgia, 1984: Atlanta, Georgia Environmental Protection Division, 83 p.

Hayes, L.R., Maslia, M.L., and Meeks, W.C., 1983, Hydrology and model evaluation of the principal artesian aquifer, Dougherty Plain, Southwest Georgia: Atlanta, Georgia Geological Survey Bulletin 97, 93 p.

Hutson, S.S., 2007, Guidelines for preparation of State wateruse estimates for 2005: U.S. Geological Survey Techniques and Methods, book 4, chap. E1, 28 p.

Hutson, S.S., Littlepage, T.M., Harper, M.J., and Tinney, J.O., 2009, Estimated use of water in Alabama in 2005: U.S. Geological Survey Scientific Investigations Report 2009-5163, 210 p.

Kenny, J.F., Barber, N.L., Hutson S.S., Linsey, K.S., and Lovelace, J.K., 2009, Estimated use of water in the United States in 2005: U.S. Geological Survey Circular 1344, 52 p.

Leitman, H.M., Sohm, J.E., and Franklin, M.A., 1984, Wetland hydrology and tree distribution of the Apalachicola River flood plain, Florida: U.S. Geological Survey WaterSupply Paper 2196-A, 52 p.

Marella, R.L., 1988, Water withdrawals, use, and trends in Florida, 1985: U.S. Geological Survey, Water-Resources Investigations Report 88-4103, 43 p.

Marella, R.L., 1990, Florida water supply and use, in National water summary 1987-Hydrologic events and water supply and use: U.S. Geological Survey Water-Supply Paper 2350, p. 207-214.

Marella, R.L., 1991, Water use in the Apalachicola-Chattahoochee-Flint River basin, 1985, in Proceedings of the 1991 Georgia Water Resources Conference, March 19-20, 1991: Athens, University of Georgia, Institute of Natural Resources, p. 9. 
Marella, R.L., 2004, Water withdrawals, use, discharge, and trends in Florida, 2000: U.S. Geological Survey Scientific Investigations Report 2004-5151, 136 p.

Marella, R.L., 2009, Water withdrawals, use, and trends in Florida, 2005: U.S. Geological Survey Scientific Investigations Report 2009-5125, 49 p.

Marella, R.L., Fanning, J.L., and Mooty, W.S., 1993, Estimated use of water in the Apalachicola-Chattahoochee-Flint River Basin during 1990 and trends in water use from 1970 to 1990: U.S. Geological Survey Water-Resources Investigations Report 93-4084, 45 p.

Mooty, W.S., 1990, Alabama water supply and use, in Carr, J.E., Chase, E.B., Paulson, R.B., and Moody, D.W., eds., National Water Summary 1987-Hydrologic events and water supply and use: U.S. Geological Survey Water-Supply Paper 2350, p. 141-148.

Pierce, R.R., 1990, Georgia water supply and use, in National Water Summary 1987-Hydrologic events and water supply and use: U.S. Geological Survey Water-Supply Paper 2350, p. 215-222.

Pierce, R.R., Barber, N.L., and Stiles, H.R., 1982, Water use in Georgia by county for 1980: Atlanta, Georgia Geologic Survey Information Circular 59, 180 p.

Pierce, R.R., Barber, N.L., and Stiles, H.R., 1984, Georgia irrigation, 1970-80: A decade of growth: U.S. Geological Survey Water-Resources Investigations Report 83-4177, 29 p.

Seaber, P.R., Kapinos, F.P., and Knapp, G.L., 1984, Hydrologic unit maps: U.S. Geological Survey Water-Supply Paper 2294, 63 p.

Stringfield, V.T., 1966, Artesian water in Tertiary Limestone in the southeastern United States: U.S. Geological Survey Professional Paper 517, 226 p.

Turlington, M.C., Fanning, J.L., and Doonan, G.A., 1987, Water use in Georgia by County, 1985: Atlanta, Georgia Geological Survey Information Circular 81, 109 p.

Tyson, A.W., and Harrison, K.A., 1993, Agricultural irrigation trends in Georgia, in Proceedings of the 1993 Georgia Water Resources Conference, April 20-21, 1993: Athens, University of Georgia, Institute of National Resources, p. 176-179.

U.S. Army Corps of Engineers, 1984, 1984 Water assessment for the Apalachicola-Chattahoochee-Flint River Basin (main report): U.S. Army Corps of Engineers Executive Summary, v. $1,88 \mathrm{p}$.

U.S. Census Bureau, 2006, Annual estimates of population for counties, April 1, 2000, to July 1, 2005 (Alabama, Florida, and Georgia): Accessed March 21, 2006, at http://www. census.gov/popest/counties/CO-EST2005-01.html.
U.S. Department of Agriculture, National Agricultural Statistic Service, 2004a, 2002 Census of agriculture, Alabama, State and county data-Vol. 1, Geographic area series, Pt. 1, AC-02-A-1: Accessed September 12, 2007, at http:// agcensus.usda.gov/Publications/2002/Volume_1,Chapter _1_State_Level/Alabama/index.asp.

U.S. Department of Agriculture, National Agricultural Statistic Service, 2004b, 2002 Census of agriculture, 2003 farm and ranch survey_-Vol. 3, Special studies, Pt. 1, AC-02-SS-1, 176 p.: Accessed September 12, 2007, at http://agcensus. usda.gov/Publications/2002/FRIS/index.asp.

U.S. Department of Commerce, 2008, National Climatic Data Center-Climate data on line: National Oceanic and Atmospheric Administration, accessed May 21, 2008, at http://cdo.ndc.noaa.gov.

U.S. Department of Energy, Energy Information Administration, 2008, EIA-767 data files, annual steam-electric plant operation and design data: Accessed November 6, 2008, at http://www.eia.doe.gov/cneaf/electricity/page/eia767.html.

U.S. Environmental Protection Agency, 1996, National Conference on Sanitary Sewer Overflows (SSOs): Washington, D.C., U.S. Environmental Protection Agency APA/625/R-96/007, accessed Sept. 20, 2010, at http://www. epa.gov/nrmrl/pubs/625r96007/625r96007.pdf.

U.S. Geological Survey, 1975, State of Alabama Hydrologic Unit Map-1974: 1 sheet, 1:500,000 scale.

U.S. Geological Survey, 1975, State of Florida Hydrologic Unit Map-1974: 1 sheet, 1:500,000 scale.

U.S. Geological Survey, 1975, State of Georgia Hydrologic Unit Map-1974: 1 sheet, 1:500,000 scale.

Verdi, R.J., Tomlinson, S.A., and Marella, R.L., 2006, The drought of 1998-2002: Impacts of Florida's hydrology and landscape: U.S. Geological Survey Circular 1295, 34 p. 


\section{Glossary}

[The following terms pertain to or are referenced in the text and are from Kenny and others (2009) and Marella (2009).]

\section{A}

aquifer A geologic formation, group of formations, or part of a formation that contains sufficient saturated material to yield substantial quantities of water to wells and springs.

agricultural water use Includes water used for irrigation and nonirrigation purposes. Irrigation water use includes the artificial application of water on lands to assist in the growing of crops and pasture, or to maintain vegetative growth in recreational lands, parks, and golf courses. Nonirrigation agricultural water use includes water used for livestock, which includes water for stock watering, feedlots, dairy operations, fish farming, and other farm needs.

\section{C}

commercial water use Water use for motels, hotels restaurants, office buildings, commercial facilities and civilian and military institutions. The water can be obtained from a publicsupply source or can be self-supplied.

consumptive use That part of water withdrawn that is evaporated, transpired, incorporated into products or crops, consumed by humans or livestock, or otherwise removed from the immediate hydrologic environment. Sometimes referred to as water consumed or water depleted. Additionally, any water withdrawn from and transferred out of the basin for use is considered 100 percent consumptively used.

cooling water Water used for cooling, such as in condensers and nuclear reactors.

\section{D}

disposal system or method Refers to injection wells, outfalls, drainfields, percolation ponds, sprayfields, and other facilities utilized for the release of reclaimed or treated effluents to the environment.

domestic wastewater facility A facility that receives or disposes of wastewater derived principally from residential dwellings, business or commercial buildings, institutions, and the like. A domestic wastewater facility may be publicly owned (by a municipality or other governmental agency) or privately owned. Also referred to as municipal wastewater facility.

domestic water use Water for normal household purposes, such as drinking, food preparation, bathing, washing clothes and dishes, flushing toilets, and watering lawns and gardens. Also called residential water use. The water can be obtained from a public supply or can be self-supplied.
$\mathbf{F}$

freshwater Water that contains less than 1,000 milligrams per liter $(\mathrm{mg} / \mathrm{L})$ of dissolved solids; generally, more than $500 \mathrm{mg} / \mathrm{L}$ dissolved solids is considered undesirable for drinking and many industrial uses. Freshwater is generally considered potable.

G

gigawatthour (gWh) A measure of electricity use equivalent to one billion watt-hours.

groundwater Generally all subsurface water as distinct from surface water; specifically, that part of the subsurface water in the saturated zone (a zone in which all voids are filled with water).

groundwater disposal Wastewater disposal through the ground either by seepage or injection. This includes the following: absorption beds, injection wells, drainfields, percolation ponds, and sprayfields (land application). Land application systems (reuse systems and sprayfields) are considered groundwater disposal methods, as the wastewater used to irrigate turf or crops is generally intended to filter down through the soil.

\section{H}

hydroelectric power water use Water use in the generation of electricity at plants where the turbine generators are driven by falling water. Hydroelectric power water use is considered an instream and generally nonconsumptive use of water.

I

industrial wastewater facility A facility that produces, treats, or disposes of wastewater not otherwise defined as domestic wastewater; includes the runoff and leachate from areas that receive pollutants associated with industrial or commercial storage, handling, or processing.

industrial water use Water used for industrial purposes, such as fabricating, processing, washing, and cooling. Includes water use for the manufacturing of steel, chemical and allied products, paper and allied products; mining; and petroleum refining. The water can be obtained from a public supply or can be self-supplied.

instream use Water use within the stream channel for such purposes as hydroelectric power generation, navigation, water-quality improvement, fish and wildlife propagation, and recreation. Sometimes called nonwithdrawal use or in-channel use.

L

Iand application The reuse of reclaimed water or the utilization or disposal of effluents on, above, or into the sprayfields, irrigation systems, or other methods. 
municipal wastewater facility See domestic wastewater facility.

\section{$\mathbf{N}$}

navigational water use Water utilized as a means of commercial (and sometimes recreational) transportation. Includes water used to lift a vessel in a lock, or maintain a navigable channel level. Navigational water use is considered a nonconsumptive instream use of water and is generally not measured or accounted for.

\section{0}

offstream use Water withdrawn or diverted from a groundor surface-water source for public-water supply, industry, irrigation, livestock, thermoelectric-power generation, and other purposes. Sometimes called off-channel use or withdrawal use.

other water use Water used for such purposes as heating, cooling, irrigation (public-supplied only), lake augmentations, and other nonspecific uses. The water can be obtained from a public supply, or can be self-supplied.

\section{$\mathbf{P}$}

per capita use The average amount of water used per person during a standard time period, generally per day. Public-supply per capita use refers to the amount of water used for public supply divided by the population served.

public supply Water withdrawn by public and private water suppliers and delivered to the public. Public suppliers provide water for a variety of uses, such as domestic, commercial, industrial, thermoelectric power (domestic and cooling purposes), and public-water use. See also domestic water use, commercial water use, industrial water use, public water use, and other water use.

public water use Water supplied from a public water-supply source and used for such purposes as firefighting, street washing, and the maintenance of municipal parks and swimming pools. Public water use also includes system water losses (water lost to leakage). Also referred to as water utility use.

\section{$\mathbf{R}$}

recycled water Water used more than one time before it returns to the natural hydrologic system or is discharged into a wastewater system. Also referred to as recirculated water.

residential water use See domestic water use.

return flow The water that reaches a ground- or surfacewater source after release from the point of use and is available for further use.
S

saline water Water that contains more than $1,000 \mathrm{mg} / \mathrm{L}$ of dissolved solids.

self-supplied water Water withdrawn from a groundwater or surface-water source by a user and not obtained from a public supply.

silviculture The cultivation of forest trees. For purposes of this report, this includes management of timberlands (areas capable of producing 20 cubic feet of industrial wood per acre per year) and woodland (areas incapable of producing 20 cubic feet of industrial wood per acre per year under natural conditions).

surface water An open body of water, such as a canal, lake, river, or stream.

surface-water disposal The release of reclaimed water or treated effluent directly into a surface-water body (including marshes or wetlands). This does not include water discharged into ponds for holding or percolation purposes.

\section{$\mathbf{T}$}

thermoelectric power Electrical power generated by using fossil-fuels (coal, oil, or natural gas), geothermal sources, or nuclear energy.

thermoelectric power water use Water used in the process of the generation of thermoelectric power. The water can be obtained from a public supply or be self-supplied. Water used for thermoelectric power generation purposes is considered an offstream use of water, and is generally nonconsumptive.

treated (wastewater) effluent Water that has received primary, secondary, or advanced treatment and is released from a wastewater facility after treatment.

\section{W}

wastewater A combination of liquid and water-carried pollutants from private residences, commercial buildings, industrial plants, and institutions, including any groundwater, surface runoff or leachate that may be present.

water transfer The artificial conveyance of water from one area to another. This may be referred to as an import or export of water from one basin or county to another.

withdrawal Water removed from the ground or diversion from a surface-water source for use. 
Prepared by:

USGS Science Publishing Network

Raleigh Publishing Service Center

USGS publishing staff:

Mike Deacon, editorial review

Ronald S. Spencer, illustrations and graphics

Twila Darden Wilson, layout and cover

For information regarding this publication, contact:

Director

USGS Florida Water Science Center

10500 University Center Dr., Suite 215

Tampa, FL 33612

http://fl.water.usgs.gov/ 

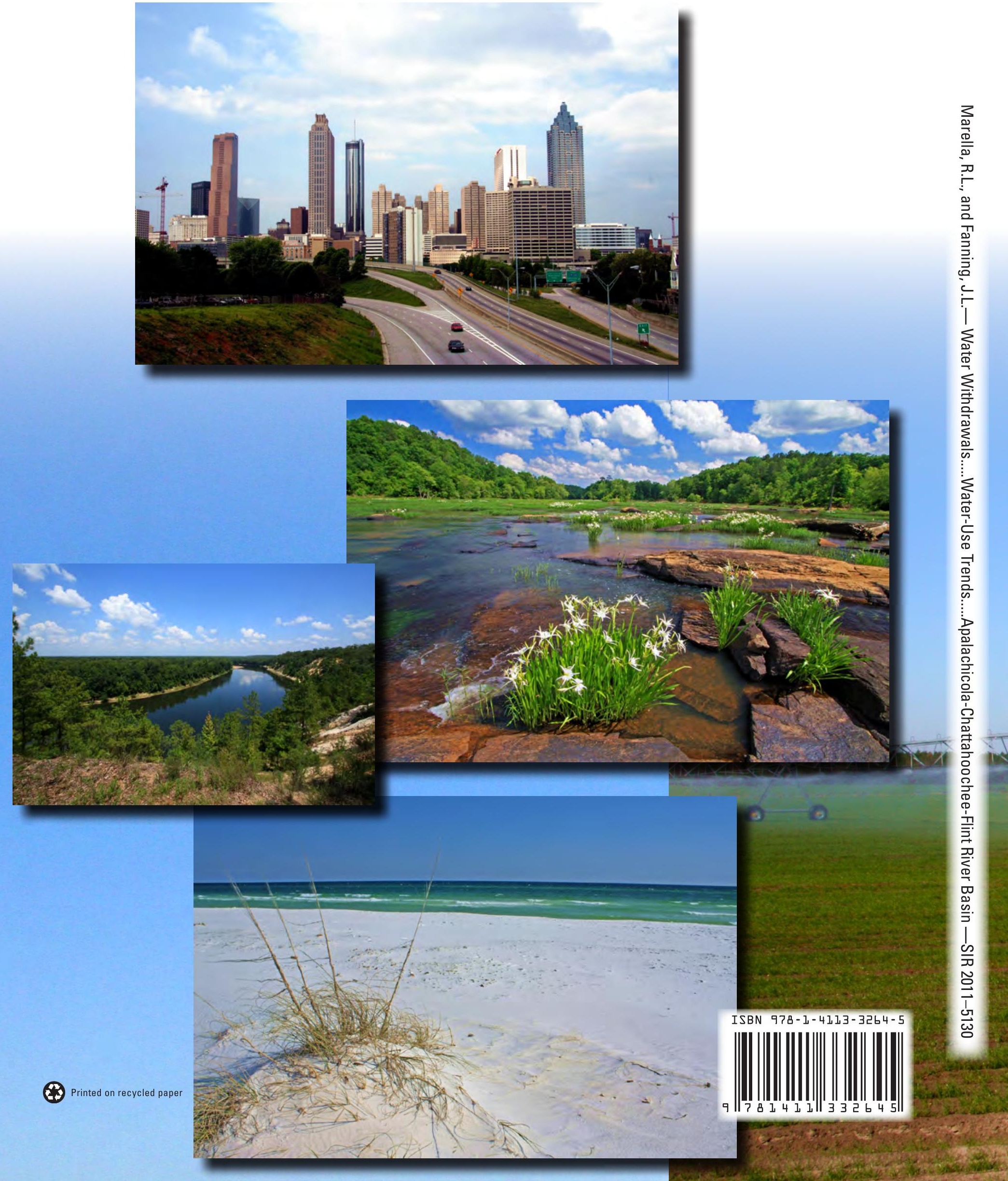